\title{
L'ambassadeur parisien de la nouvelle musique hongroise, Géza Vilmos Zágon Sa carrière et sa correspondance choisie ${ }^{1}$
}

\author{
Boglárka ILLYÉS \\ Bibliothèque nationale Széchényi, Département de musique \\ Budavári Palota F épület, 1827 Budapest, Hongrie \\ E-mail: illyes.boglarka@gmail.com
}

(Reçu : mars 2017; accepté : mai 2017)

\begin{abstract}
A forgotten figure of the new Hungarian musical movement of the 1910s, Géza Vilmos Zágon (1889-1918) was a talented composer, pianist and music writer. He belonged among those young composers who turned toward French culture instead of the traditional German orientation and searched for new inspiration in Paris. He was, at the same time, one of the few to be personally acquainted with leading personalities of the city's musical life: letters by Claude Debussy, Michel-Dimitri Calvocoressi, Louis Laloy, Émile Vuillermoz and Albert Zunz Mathot have survived in his legacy. During his stay in France between 1912 and 1914, he acted as the representant of the former UMZE (Új Magyar Zene Egyesület, New Hungarian Music Association), and did not only bring attention to himself as a performer of his own works, but was also instrumental in promoting those by Bartók and Kodály. In the present study, I seek to demonstrate that Zágon served as an important liaison for Bartók's circle with some of the most influential groups of French avant-garde, the Société Musicale Indépendante, as well as Calvocoressi. In an effort to document these important relationships as well as Zágon's activity, I publish a selection of his correspondence in original language, with French translation provided where appropriate.
\end{abstract}

Keywords: new Hungarian music, Paris, Géza Vilmos Zágon, correspondence, avant-garde

Compositeur, pianiste et écrivain musical hongrois, Géza Vilmos Zágon (18891918) appartenait au groupe de compositeurs autour de Béla Bartók et de Zoltán

1. La version hongroise de cette étude a été publiée sous le titre «Az új magyar zene párizsi követe. Zágon Géza Vilmos pályája és levelezése » dans Lymbus Magyarságtudományi Forrásközlemények 2014 (2015), 323-358. <http://epa.oszk.hu/01500/01500/00011/pdf/EPA01500_lymbus_2014_323-358.pdf> Traduction française et révision de l'auteur. Je tiens à remercier vivement Denis Herlin pour son aide précieuse et ses commentaires utiles lors de l'élaboration de la version française. 
Kodály. Sans doute injustement oublié par la postérité, ce musicien francophile, talentueux fut pourtant tenu en haute estime par ses contemporains. Dans les années précédant la Première Guerre mondiale où il demeurait à Paris, alors à l'apogée de sa carrière tragiquement courte, il entretenait des relations personnelles avec les personnalités influentes de la vie musicale parisienne aussi bien qu'avec celles de la capitale hongroise. Aussi, le legs des papiers de Zágon à la bibliothèque nationale hongroise offre de précieuses sources pour les historiens de la musique et pour l'histoire des relations musicales franco-hongroises à l'aube du $\mathrm{XX}^{\mathrm{e}}$ siècle : celui-ci inclut des lettres plus ou moins longues de Claude Debussy, de Michel-Dimitri Calvocoressi, de Louis Laloy, d'Émile Vuillermoz et d'Albert Zunz Mathot, ainsi que celles de Dezső Demény, de Jenő Hubay et de Pongrác Kacsoh. ${ }^{2}$ La plupart d'entre elles sont publiées à la fin de ce texte. En outre, Zágon était régulièrement en contact avec Béla Bartók et Zoltán Kodály pendant son séjour à Paris entre 1912 et 1914. Pour compléter sa correspondance avec Béla Bartók - connue depuis longtemps ${ }^{3}$-, nous donnons également à la fin de ce texte les lettres adressées à Kodály, qui sont conservées dans les archives du célèbre compositeur.

En publiant ces sources, nous souhaitons mettre en lumière les relations peu connues que Zágon établit, dans les années 1910, avec les milieux de l'avant-garde musicale parisienne pour promouvoir « la jeune école hongoise ». Non seulement il faisait partie de la Société Musicale Indépendante récemment fondée par Ravel et ses amis, mais il servait aussi d'intermédiaire avec les réseaux informels non moins influents : disciple et proche de Debussy, il était lié au cercle étroit des amis du maître ; grâce à Vuillermoz et à Laloy, qui étaient également des amis de Ravel, il pouvait entrer en relation directe ou indirecte avec le groupe artistique nommé « les Apaches », dont Calvocoressi fut un membre actif. ${ }^{4}$ Les lettres émanant des personnes mentionnées ci-dessus nous offrent des renseignements sur l'activité parisienne de Zágon ainsi que sur la réception de la nouvelle musique hongroise en France. Par ailleurs, d'autres en langue hongroise du legs Zágon nous aident également à comprendre les conflits qui pesèrent sur la vie musicale hongroise de l'époque, ainsi que l'importance de cette relation française pour le groupe. Enfin, grâce à ces documents émanant de personnages marquants de la

2. Le legs Zágon ne constitue pas un fonds dans les collections de la Bibliothèque nationale Széchényi (H-Bn). Mais une liste dressée au moment de son acquisition permet de le reconstituer : il comprenait quarante-sept lettres, seize partitions manuscrites, trois partitions imprimées, ainsi que quelques autres documents imprimés et photographies.

3. Géza Vilmos Zágon, « Briefe an Bartók », éd. Denis Dille, in Documenta Bartókiana (Budapest : Akadémiai, 1965), vol. 2, 18-27, ainsi que Bartók Béla levelei, éd. János Demény (Budapest : Zeneműkiadó, 1976), 202-209.

4. Sur les cercles musicaux d'avant-garde parisiens, voir, Illyés, Boglárka, « Az új magyar zene Párizsban 1910-1914 : Zágon Géza Vilmos és a francia kapcsolat », in Tér(v)iszonyok és tér-kép(zet)ek, éd. Bíró Csilla et Visy Beatrix (Budapest : Gondolat-OSZK, 2014) = Bibliotheca Scientiae et Artis, 157-173. 
vie musicale, il est possible de mieux cerner la figure effacée du destinataire, et de reconstruire sa biographie.

Issu d'une famille de commerçants aisée d'origine juive, germanophone, Zágon est né sous le nom de Vilmos Zerkowitz, le 3 octobre 1889 à Budapest. Son père était Zsigmond Zerkovitz, grand marchand de vin, sa mère Ernesztine Weissmayer. ${ }^{5}$ Son frère Sándor deviendra ingénieur et vivra à Berlin entre les deux guerres mondiales ; c’est lui qui vendit le legs Zágon, en 1942, à la Bibliothèque nationale Széchényi. ${ }^{6}$ Bien que le nom du père s'écrive avec un $\mathrm{W}$ dans le registre des naissances tenu par la communauté juive néologue de Pest, la famille ${ }^{7}$ - comme le cousin célèbre de Zágon, le compositeur Béla Zerkovitz -, utilisait la forme hongroise du nom. ${ }^{8}$ Ainsi, le jeune étudiant en composition était inscrit comme «Zerkovitz Vilmos » dans les registres de l'Académie de musique de Budapest jusqu'en 1909, où il adopta le nom de Zágon (référence explicite au lieu de naissance de Kelemen Mikes, homme de lettres hongrois) et le vieux prénom hongrois de Géza. Officiellement, son changement de nom eut lieu le 11 août 1909, après qu'il se fut converti au christianisme et qu'il fut admis, le 5 juillet 1909, dans l'église évangélique de langue hongroise de Pest.

Il avait étudié le piano, en privé, avec le professeur retraité de l'Académie de musique Henri Gobbi. ${ }^{9}$ Ancien élève et ami de Liszt, Gobbi fut aussi un compositeur reconnu. ${ }^{10}$ Certains documents du legs témoignent d'une relation personnelle étroite entre le maître et son élève. Dans une de ses lettres, Gobbi signe comme « professeur et ami » du jeune musicien, ${ }^{11}$ tandis que Zágon dédiera sa Sonate en ré bémol majeur, publiée en 1914, à son « cher maître ». Il entretiendra avec lui une correspondance pendant ses années parisiennes.

Zágon fut probablement initié par Gobbi à l'harmonie et à la composition, car il n’accomplit que les deux dernières années d'études en composition à l'Académie

5. Pour les principales données personnelles et le changement de nom, voir son inscription au registre des naissances dans les Archives de la Ville de Budapest (HU BFL-XV.20.2.-A 31-Egyházi akv., izraelita neológ, Pest-2025. sz.).

6. Registre des acquisitions effectuées par la Bibliothèque nationale Széchényi [H-Bn], 1942/11.405. Sándor (Alexander) Zerkowitz (1881-?) déploya en Allemagne une activité importante en tant qu'ingénieur en génie électrique. Il a dû être obligé de s'enfuir en Hongrie au moment de la montée du nazisme. Nous n'avons aucune information sur lui après 1942, sinon que dans les années 1950, il travaillait au Ministère de l'Industrie métallurgique et mécanique, à Budapest.

7. La famille appartenait à la branche de Pest nommée « Eszter » des Zerkowitz, voir l'arbre généalogique <http://www.zerkovitz.hu> (Date de consultation : 24 juillet 2014)

8. Voir par ex. les actes notariés relatifs aux compagnies de son père («Zerkovitz Zsigmond és társa », « Nord és Zerkovitz ») dans les Archives de la Ville de Budapest.

9. Pour la question des premières études de musique de Zágon, voir une lettre en langue allemande de Gobbi à «Wilhelm Zerkowitz », du 3 août 1906 (H-Bn, Département des Manuscrits, Fond XII/349), ainsi que son bref curriculum vitae rédigé pour le jury du concours auquel il participa en 1911 ; [Lajos Nagy], A Ferencz József koronázási jubileum-díj (Budapest, 1976), (manuscrit, Bibliothèque centrale Szabó Ervin de Budapest, Collection de Budapest), 222-223.

10. Szilvia Gyöngyösi, « Gobbi Henrik, a Zeneakadémia zongoratanára : Liszt és Gobbi kapcsolata », Muzsika 44/10 (2001 október), 34.

11. Lettre mentionnée dans la note 9. 
de musique de Budapest entre 1907 et 1909. Néanmoins, il remplit parfaitement les conditions requises pour obtenir le diplôme de l'Académie ${ }^{12}$ il est même mentionné comme l'un des étudiants les plus remarquables dans l'Album-souvenir de l'institution paru en $1925 .{ }^{13}$ D'après les rapports annuels de l'Académie, Zágon fut, dans l'année scolaire 1907/1908, l'élève d'un des plus grands pédagogues de l'Académie, János Koessler, maître aussi de Bartók, Kodály et de Dohnányi. Puis, après la retraite de celui-ci, il poursuivit ses études de composition sous la direction de Viktor Herzfeld, homme de haute culture européenne.

Après avoir obtenu son diplôme en 1909, Zágon s'inscrivit de nouveau à l'Académie de musique comme redoublant volontaire, mais ne fréquenta pas les cours durant cette année scolaire. ${ }^{14} \mathrm{Si}$ l'on en croit sa nécrologie, il partit pour un voyage d'études de plusieurs mois à Paris ${ }^{15}$ au printemps de 1910 : en effet, Bartók demande, dans une de ses lettres adressées à Sándor Kovács à Paris après le festival hongrois, où il doit renvoyer les mélodies que Zágon lui avait envoyées. ${ }^{16}$ Ainsi, Zágon était sans doute présent à la soirée hongroise le 12 mars 1910 et avait sans doute collaboré à l'organisation de ce concert de musique de chambre qui s'était tenu dans la salle de concert de l'Hôtel des Modes. Ce fut un événement musical majeur, le premier à attirer l'attention des avant-gardistes sur la nouvelle école des compositeurs hongrois en voie de formation, avec au programme : le Trio à cordes en sol mineur de Leó Weiner, la Sonate pour violoncelle et piano opus 4 de Zoltán Kodály, ainsi que douze des Bagatelles, une Fantaisie ${ }^{17}$ et la première Danse roumaine de Béla Bartók, interprétées par le compositeur lui-même, outre les œuvres récentes d'Ödön Michalovich, d'Árpád Szendy et d’Ernő Dohnányi. Parmi les personnalités de renom qui assistèrent au festival hongrois, il y avait notamment les musicologues Louis Laloy et Jules Écorcheville, ainsi que le critique musical Émile Vuillermoz. ${ }^{18}$

Zágon n'était qu'un des nombreux jeunes musiciens hongrois qui passèrent, à l'aube du $\mathrm{XX}^{\mathrm{e}}$ siècle, plus ou moins de temps à Paris, capitale culturelle du monde

12. Az Országos Magyar Királyi Zene-Akadémia Évkönyve az 1908-1909-diki tanévröl, éd. Géza Moravcsik (Budapest : Athenaeum, 1909), 167.

13. Az Orsz. Magyar Királyi Zenemüvészeti Föiskola Jubileumi Emlékkönyve 1875-1925 (Budapest : Orsz. M. Kir. Zenemüvészeti Főiskola, 1925), 195.

14. Registre des élèves de l'Académie royale de musique de Budapest, 1909/10. (Archives de l'Université de musique Franz Liszt). Inscription no. 444, du 7 janvier 1910.

15. «Zágon Géza Vilmos meghalt », Zenei Szemle 2/9 (1918. november), 344. L'information est confirmée par Antal Molnár, «Zágon Géza Vilmos » in idem, Magamról, másokról (Budapest : Gondolat, 1974), 193.

16. Demény, Bartók Béla levelei, 164. Sándor Kovács (1886-1918) - compositeur, pianiste, musicologue et excellent pédagogue musical, expert en musique baroque. Avant juin 1910, il vécut longtemps à Paris.

17. L'œuvre intitulée sur le programme «Fantaisie » et créée ici a été identifiée par László Somfai comme la seconde pièce de ce qu'on éditera plus tard sous le titre Deux élégies : László Somfai, « Desiderata Bartókiana : a Survey of Missing Links in Bartók Studies », International Journal of Musicology 9 (2000), 410.

18. Jules Écorcheville (1872-1915) - musicologue, l'un des directeurs, avec Louis Laloy, du Mercure musical / Revue musicale S.I.M., président de la Société Internationale de Musique (à partir de 1912). Il n'existe pas de document de la main d'Écorcheville et provenant du legs, mais leur relation est plusieurs fois évoquée par Zágon dans sa correspondance avec Kodály et Bartók. 
d'alors. Venus en «pèlerinage », peu d'entre eux cependant firent la connaissance des personnalités influentes de la vie musicale parisienne. Surtout Debussy, très respecté en Hongrie, avait la réputation d'être un homme peu accessible. Par extrême modestie peut-être, le jeune Kodály n'essaya même pas de s'approcher de lui durant son séjour à Paris en $1907,{ }^{19}$ ou encore en décembre 1910, lors de la visite du maître français à Budapest. Quant à Bartók, il se rendit plusieurs fois en France dans le dessein de se faire remarquer et de nouer des contacts, mais ses tentatives restèrent infructueuses avant le festival hongrois. Sa participation au concours Anton Rubinstein de 1905 fut un échec. En 1909, malgré de sérieuses recommandations, il ne réussit pas à percer dans les cercles musicaux parisiens, et la rencontre souhaitée avec Debussy n'eut pas lieu, ni alors, ni l'année suivante à Budapest. ${ }^{20}$

En effet, peu nombreux étaient ceux avec qui Debussy entretenait une relation étroite. Parmi les quelques personnes hongroises dont il fit connaissance à Budapest étaient Gusztáv Bárczy, co-propriétaire de la maison d'édition de musique Rózsavölgyi \& Co., l'organisateur de son concert, et les membres du Quatuor Waldbauer-Kerpely qui créèrent avec un grand succès son Quatuor à cordes en sol mineur. Il est vrai que Debussy appréciait beaucoup ses amis hongrois, comme en témoignent des lettres amicales, ${ }^{21}$ des invitations à Paris et un portrait photographique avec une dédicace autographe à Imre Waldbauer. ${ }^{22}$

Outre un portrait similaire de Debussy, ayant autrefois appartenu à Zágon, qu'il a malheureusement été impossible de retrouver, ${ }^{23}$ deux autres précieux documents du legs attestent de la relation entre Zágon et Debussy : le manuscrit autographe du Pierrot lunaire de Zágon avec ajouts et corrections de Debussy, ainsi qu'une lettre d'accompagnement autographe signée du maître français. Tout comme le mélodrame de Schönberg, le cycle de mélodies du compositeur hongrois met en musique les poèmes d'Albert Giraud, poète symboliste belge. Mais le Pierrot lunaire de Zágon est composé sur un choix de six poésies en langue originale, est d'un genre musical différent et, de plus, il est antérieur à celui de Schönberg. Zágon composa ces mélodies entre octobre 1908 et septembre 1909, durant ses années d'études à l'académie. ${ }^{24}$ Cela démontre bien que déjà à cette date, il vivait dans la proximité spirituelle de l'avant-garde parisienne et l'esthétique symboliste ne lui était pas inconnue.

19. Anna Dalos, Forma, harmónia, ellenpont : Vázlatok Kodály Zoltán poétikájához (Budapest : Rózsavölgyi és Társa, 2007), 154.

20. Alain Surrans, Bartók et la France (Budapest : Európa-Institut français en Hongrie, 1993), $25-42$.

21. Voir Claude Debussy, Correspondance (1878-1914), éd. François Lesure et Denis Herlin (Paris : Gallimard, 2005).

22. László Fábián, Debussy élete, kora és müvészete (Budapest : Zeneműkiadó, 1957), 88-89.

23. Ce document figure sous la côte « arcképgyüjtemény 254 » sur la liste du legs Zágon (H-Bn, Département des Manuscrits, registre du Fonds des lettres musicales).

24. H-Bn, Département de la Musique, Ms. mus. 2.022. 
Selon toute vraisemblance, Zágon fit parvenir le manuscrit de son œuvre à Debussy, par l'intermédiaire de la compagnie Rózsavölgyi, après le concert du maître à Budapest en décembre 1910. Debussy y apporta ses corrections et lui retourna le manuscrit accompagné d'une lettre datée du 22 janvier 1911 (Source 1). Il avait aussi fait mention de Zágon dans sa lettre de remerciement à Gusztáv Bárczy, écrite peu après sa visite budapestoise, en faisant allusion à l'œuvre qu'il venait de recevoir. Ses lignes peuvent être considérées comme une recommandation pour le jeune compositeur, encore sans éditeur. «J'ai reçu de la musique de notre ami Guillaume Zágon dont vous pouvez être assuré que je vais m'occuper. Il est en effet très gentil et plein d'avenir ! $\gg^{25}$

Zágon appartenait probablement au cercle très limité de jeunes compositeurs que Debussy trouvait remarquables et qu'il encourageait et recevait chez lui. ${ }^{26}$ Certains documents provenant du legs indiquent que le jeune compositeur a fréquenté à plusieurs reprises la maison de Debussy entre 1912 et 1914. Dans un court message à Zágon de mars 1914, Mme Emma Debussy l'informe de la maladie de son mari et lui demande de remettre sa visite de lundi matin à la semaine suivante. ${ }^{27}$ Une autre preuve de leurs relations provient d'une lettre d'Andor Merkler de septembre 1912, qui, par l'intermédiaire de Zágon, fait savoir à Debussy que l'Opéra de Budapest souhaite présenter L'Enfant prodigue. ${ }^{28}$ Enfin, malgré qu'aucune lettre de Debussy à Zágon datant de son séjour parisien n'ait survécu, il est frappant de constater que ce dernier cite abondamment les mots du maître dans ses articles, ce qui témoigne indirectement de leurs contacts personnels. ${ }^{29}$

Nous ne connaissons pas les circonstances de la première rencontre du jeune compositeur avec Debussy. En raison de leur profondeur et de leur actualité, les trois études de Zágon, parues dans le numéro du $1^{\text {er }}$ décembre 1910 de Zeneközlöny (Bulletin de musique), ${ }^{30}$ montrent toutefois clairement qu'il avait eu largement la possibilité, avant cette date, d'étudier les œuvres du maître français. L'essai introductif fut probablement écrit quelques mois avant la date de parution, car il semble que ce soit ce texte que Zágon envoyât, en été de cette année-là, à Frigyes Reiner à Ljubljana - un camarade de classe de l'Académie travaillant alors

25. Lettre du 19 décembre 1910, voir C. Debussy, Correspondance (1872-1918), 1361. Un extrait de cette lettre de Debussy a été publié en fac-similé, la lettre complète en traduction hongroise par Viktor Lányi dans son article «Debussy és a magyar népzene : A nagy francia zeneköltő ismeretlen, magyar vonatkozású levele », Pesti Hírlap 59/293 (1937. december 25.), 38.

26. Pour le caractère de Debussy et la question de sa sociabilité, voir Robert Orledge, « Arcképvázlat Debussyröl 1-2 », Muzsika 55/88 (2012. augusztus), 8-9.

27. H-Bn, Département des Manuscrits, Fond XII/200.

28. H-Bn, Département des Manuscrits, Fond XII/753, Ep. Mus. 1224/a. Andor Merkler (1862-1920) critique musical, compositeur hongrois.

29. À titre d'exemple, «Zenei élet Párisban », Zeneközlöny 11/17 (1913. április 15.), 555-556.

30. « Claude Debussy », Zeneközlöny 9/3 (1910. december 1.), 74-80. « Debussy müveiről », ibid., 81-87; « Debussy: g moll vonósnégyes », ibid., 91-95; « Az előadásra kerülő zongoradarabok méltatása », ibid., 96. 
comme chef d'orchestre au théâtre national de Slovénie,$-{ }^{31}$ auprès de qui il se renseigna aussi sur un poste de chef d'orchestre secondaire et d'accompagnateur. ${ }^{32}$ Dans le début de son article « Les œuvres de Debussy », Zágon décrit la lutte de la musique d'avant-garde contre le conservatisme myope, ce à quoi Reiner pouvait faire allusion en félicitant son ami : « Il est très intéressant de mettre le sujet dans le contexte de notre vie musicale actuelle. Tu as découvert pas mal de traits nouveaux et appropriés - ça se voit que tu connais bien la „Vieille Branche” $»{ }^{33}$ De même, dans la première monographie sur Debussy, parue en 1957, László Fábián fait l'éloge de Zágon en commémorant son activité de propagation : « [...] Pionnier, Zágon était non seulement le commentateur le plus fiable et le plus profond de Debussy, mais aussi son premier interprète hongrois qui s'approchait de son art avec affection, enthousiasme et compréhension. $»^{34}$ À l'âge de vingt et un ans à peine, Zágon est devenu un expert et un propagateur reconnu - par le maître luimême - de l'art de Debussy, et est toujours considéré comme tel de nos jours dans la littérature spécialisée.

Ses brillants écrits sur Debussy marquent le début d'une carrière de musicographe. De 1910 à 1912, il publia plusieurs articles concernant les actualités de la vie musicale hongroise, aussi bien dans Zeneközlöny que dans les revues A Zene (La Musique) et Aurora. Dans cette dernière revue, il fit paraître notamment une critique sur le concert français du 6 février 1911 de l'Orchestre de l'Académie, dont le programme comprenait aussi, dans sa traduction, du texte de la cantate L'Enfant prodigue, dont l'auteur était Édouard Guinaud. ${ }^{35}$ À la suite du concert hongrois de ce même orchestre, qui eut lieu le 27 mars 1911, il écrivit un article à la louange du jeu de piano de Bartók et de ses deux œuvres au programme : la Danse roumaine No. 2, créée ici, et la Suite No. 1 pour orchestre. ${ }^{36}$ On peut citer, parmi ses écrits importants, ses douze essais parus sous le titre «Beethoven zongoraszonátái esztétikai megvilágításban » (Les sonates pour piano de Beethoven d'un point de vue esthétique), ${ }^{37}$ et surtout son article « Gondolatok régi és új

31. Frigyes Reiner (1888-1963) - chef d'orchestre hongrois de réputation internationale, suivit des études de piano et de composition à l'Académie de musique.

32. Lettre de Reiner à Zágon, Laibach, 9 octobre 1910 (H-Bn, Département des Manuscrits, Fond XII/908, Ep. mus. 1225/a)

33. Carte postale de Reiner à Zágon, Laibach, non datée mais datable du 6 août 1910. (H-Bn, Département des Manuscrits, Fond XII/908, Ep. mus. 1225/b).

34. Fábián, Debussy élete, 195.

35. «Francia hangverseny », Aurora 1/2 (1911. február), 110-112. Date et programme du concert : H-Bn, Département des Affiches et des Imprimés de petit format, Zenei apró, Budapest 1911/febr. Le livret: Debussy, Claude, A tékozló fiú. Szöveg Edmond [sic pour Édouard] Guinaud. Ford. Zágon Géza Vilmos. Bp., 1911. (HBn, Département de l'Histoire du Théâtre, MM 13.998).

36. « Magyar hangverseny », Aurora 1/4 (1911. április 8.), 42-43. Sur le concert, voir Demény János, Bartók Béla müvészi kibontakozásának évei : Találkozás a népzenével (1906-1914), in Liszt Ferenc és Bartók Béla emlékére, éd. Szabolcsi Bence et Bartha Dénes (Budapest : Akadémiai, 1955) = Zenetudományi tanulmányok 3, 389-390.

37. Cette série d'essais vit le jour dans les numéros parus entre février 1911 et févier 1912 de la revue A Zene. 
muzsikáról » (Réflexions sur l'ancienne et la nouvelle musique). ${ }^{38} \mathrm{Ce}$ dernier écrit, qui salue l'édition parisienne de la collection de musique ancienne et des œuvres originales pour piano de Sándor Kovács, reflète de manière caractéristique l'intérêt spécial que portaient les partisans de la nouvelle musique hongroise pour la musique ancienne, c'est-à-dire la musique baroque découverte sous l'influence de l'avant-garde parisienne, d'autre part, pour la musique folklorique authentique que Bartók et Kodály recueillaient à l'aide des appareils modernes. Zágon place au centre de sa réflexion la musique de Bartók, qui est originale bien que s'inspirant du folklore, et notamment sa série Gyermekeknek (Pour les enfants) qui venait justement d'être achevée : voilà l'œuvre qu'il veut mettre en avant, en dressant un parallèle entre les deux sources d'inspiration, dans un contexte international. Et c'est également Bartók, apparenté à Liszt et à Bach, qu'il élève sur un piédestal, en fin de compte, dans sa critique du concert consacré à Liszt et donné le $1^{\text {er juin }}$ 1911 par l'Orchestre de l'Académie. ${ }^{39}$

En tant qu'auteur et cosignataire de la fameuse « Déclaration » publiée en janvier 1912 dans Zeneközlöny, ${ }^{40}$ il soutenait la cause de Sándor Kovács qui se faisait critiquer pour son article intitulé «La jeune école hongroise», paru dans le numéro de novembre 1911 de la Revue musicale S.I.M. L'essai de Kovács, rendant compte en France de la formation du nouveau mouvement musical hongrois, fut recensé par Kálmán Isoz dans Zeneközlöny, ce qui déclencha une polémique dans les colonnes du journal. L'affaire provoqua, entre le rédacteur Dezső Demény et les jeunes collaborateurs du journal ayant signé la déclaration, un petit conflit que les deux parties souhaitaient résoudre. Selon Demény, qui exhortait Zágon et ses camarades à continuer leur contribution à la revue, l'antagonisme résulta de ce que les deux courants musicaux, représentés par Isoz et Kovács, étaient séparés par un abîme qui semblait infranchissable (Source 2). Cette querelle relève d'une division profonde de la société musicale hongroise. D'un côté, on trouve un groupe de jeunes compositeurs ambitieux - Bartók, Kodály, Weiner, Zágon, Kovács et autres - qui cherchaient de nouvelles sources d'inspiration et qui étaient, à quelques exceptions près, de fervents adeptes de la culture française. De l'autre côté, il y avait les conservateurs (ou considérés comme tels par les premiers) qui étaient favorables à la traditionnelle orientation austro-allemande de la culture hongroise - Árpád Szendy, Béla Szabados, Ödön Michalovich, Jenő Hubay etc. -, et qui dominaient par leur personnalité la vie musicale hongroise.

Entre 1910 et 1912, Zágon se produisit en concert à Budapest aussi bien comme compositeur que pianiste. Le 14 mai 1910, il joua, lors d'un concert public de l'Académie de musique, sa Sonate en mi bémol majeur ainsi que le mouvement

38. Zeneközlöny 9/9 (1911. március 1.), 269-275.

39. «Liszt », Zeneközlöny 9 /14 (1911. június 15.), 462-464.

40. Imre Balabán-Jenő Fenyves-Géza Vilmos Zágon, « Nyilatkozat », Zeneközlöny 10/10 (1912. január 29.), 334-335. 
«Idylle » de son cycle Poèmes..$^{41}$ Cette œuvre, qui est son premier opus, parut en 1911 chez Rózsavölgyi. ${ }^{42}$ Au concert du 12 février 1911 du Quatuor de Harry Son, il créa la Sonate pour violoncelle et piano en ré mineur de Károly Henschel. Son « Idylle» fut interprétée le 21 mars de cette même année par Rudolf Ganz. Un article par Jenő Fenyves paru dans le numéro du $1^{\text {er }}$ avril 1911 de Zeneközlöny relate un récital, donné par lui et Imre Balabán, où Zágon « joua Debussy et Bartók avec une force quasi créatrice » et créa plusieurs de ses propres compositions : après le mouvement «Élégie » de Poèmes, des œuvres vocales avec Dezső Róna et Rózsika Marschalkó, plus précisément l'une de ses mélodies d'Endre Ady (« Fehér lyány virág kezei / Blumenhände des weissen Mädchens » dédiée à la pianiste Ilonka Kabos ou « Mystères », composée sur le poème "A rémmesék uhuja ») et cinq mélodies du Pierrot lunaire. ${ }^{43}$ L'auteur ne manque pas de mentionner que le concert «ne pouvait avoir lieu sans jouer la vieille comédie archi-connue », c'est-à-dire, le moins de gens possible l'écoutèrent et des critiques malveillantes, n'ayant pas beaucoup d'égards aux considérations artistiques parurent le lendemain. Lors d'un récital de sonates avec Harry Son, donné le 19 décembre 1911 à la salle Royal, il joua aussi, d'après son manuscrit, la Sonate pour violoncelle et piano opus 4 de Kodály avec l'artiste d'origine hollandaise. Ils exécutèrent l'œuvre dans sa forme en deux parties, annonçant la version définitive. ${ }^{44}$ Malgré leur interprétation convaincante pour l'auteur, les jeunes artistes n'eurent pas l'espoir de plaire au public. ${ }^{45}$

Ce fut encore en avril 1911 que Zágon joignit l'Association de la Nouvelle Musique Hongroise (Új Magyar Zene-Egyesület, abréviée en hongrois UMZE) qui se formait alors sous la direction de Béla Bartók, Zoltán Kodály, Leó Weiner, Sándor Kovács, Dezső Demény, Pongrác Kacsoh et d’Ákos Buttykay. Lassociation avait pour but premier de faire connaître la nouvelle musique, mais aussi l'ancienne qui s'entendait rarement ; plus généralement, elle se donna pour mission de développer la vie musicale en Hongrie par le biais de concerts, de conférences destinées à un large public et d'autres moyens. À l'origine, la mise en place d'un orchestre figurait aussi parmi les objectifs primordiaux, mais faute de subvention, ce projet n'aboutit pas et, ainsi, le domaine d'activité de l'UMZE allait donc se limiter à la

41. H-Bn, Département des Affiches et des Imprimés de petit format, Zenei apró, Budapest 1910/55/a. La sonate en question peut être identifiée par les titres des mouvements. Sonate : Mi bémol majeur, pour le piano par Guillaume G. Zágon. (Manuscrit, H-Bn, Département de la Musique, Ms. mus. 2.018).

42. Poèmes : I. Idylle : II. Danse des Faunes : III. Elégie, pour le piano par Vilmos Géza Zágon, op. 1 (Budapest-Leipzig : Rózsavölgyi et Cie, 1911).

43. Jenő Fenyves, « Marschalkó Rózsi, Róna Dezső, Zágon Vilmos », Zeneközlöny 9/11 (1911. április 1.), 347-349.

44. Les titres des mouvements comme indiqués sur le programme : 1. Fantasia. Andante et 2. Allegro commodo - Adagio. (H-Bn, Département des Affiches et des Imprimés de petit format, Zenei apró, Budapest 1911/dec.).

45. «Il est fort douteux que [la Sonate de Kodály] plaise au grand public », écrivit Harry Son à Zágon au stade de la conception du concert, dans sa lettre en langue allemande du 11 octobre 1911. (H-Bn, Département des Manuscrits, Fond XII/1009). 
musique de chambre. Lors du troisième concert du 12 janvier 1912 et du quatrième et dernier, qui eut lieu le 22 mars, Zágon pouvait présenter trois de ses œuvres : en janvier, la Sonate II, en mars, une mélodie d'Ady et la Sonate en ré bémol majeur. ${ }^{46}$ De courte existence, l'association lutta pour sa survie en avril 1912. Le fait que Bartók et Kodály, déçus, quittèrent l'entreprise, conduisit à sa dissolution complète. ${ }^{47}$ Pour l'heure, donc, la nouvelle musique hongroise ne jouissait ni de la faveur du grand public, ni de celle de l'élite musicale officielle. Ses deux principaux chefs - dont Bartók qui se retira en raison aussi du refus de son opéra $L e$ château de Barbe-Bleue - se virent de plus en plus isolés.

Peu après la dissolution de l'UMZE, Zágon se dirigea de nouveau vers Paris. À cette époque, il se distinguait déjà par son talent de pianiste et de compositeur ainsi que par ses écrits musicaux de haut niveau. Lors du concours mis en place par le Conseil de la Ville de Budapest en 1911, il remporta - suite à la recommandation de Géza Moravcsik, secrétaire de l'Académie de musique $-{ }^{48}$ le « Prix du jubilé du couronnement de François-Joseph ${ }^{49}{ }^{49}$ C'était - un peu comme le Prix de Rome - une bourse d'étude permettant aux jeunes artistes de se former en étranger. Selon le bulletin officiel de Budapest, la prestigieuse récompense musicale, ouvrant droit à une pension de 3200 couronnes pendant deux ans, fut attribuée à Zágon unanimement le 24 février 1912, en accord avec la proposition de Pongrác Kacsoh, le rapporteur spécial sur la musique du Conseil de Budapest. ${ }^{50}$ Cette bourse donna à Zágon la possibilité d'effectuer un séjour plus long à Paris : en suivant sa correspondance, nous savons qu'il habita 3 , rue de l'Odéon, à part quelques brèves interruptions, jusqu'en mai 1914, et qu'il avait l'intention d'y retourner en septembre.

Il subsiste peu d'information sur les premiers mois de son activité parisienne. Quoi qu'il en soit, au bout de quelques mois, son nom n'était pas complètement inconnu dans les milieux musicaux : le numéro de décembre 1912 de la Revue musicale S.I.M. rend compte de Poèmes, son premier opus publié en $1911 \mathrm{chez}$ Rózsavölgyi. ${ }^{51}$ Les lettres d'Andor Merkler nous informent qu'en automne 1912, avec l'aide de Merkler, Zágon négocia avec le metteur en scène Sándor Hevesi au sujet de la première de L'Enfant prodigue à l'Opéra de Budapest. Il semble

46. Voir les programmes de concert de Zeneközlöny, du 5 janvier 1912 et du 11 mars 1912 . Une critique sur le concert de mars : Róbert Berény, « Az U.M.Z.E. márciusi 22-i hangversenyén », Nyugat 5/7 (1912. április 1.), 647-649. Il subsiste deux sources manuscrites de la Sonate en ré bémol majeur à Budapest: H-Bn, Département de la Musique, Ms. mus. 2017 et Ms. mus. 5.135, dont la première est un manuscrit autographe qui provient du legs Zágon. Aucun des deux manuscrits ne semble conserver la version originale de l'œuvre qui a été plus tard retravaillée par Zágon, voir Dille, Briefe an Bartók, 21, 23.

47. Lynn Hooker, « Modernism on the Periphery : Béla Bartók and the New Hungarian Music Society of 1911-1912 », Musical Quarterly 88/2 (Summer 2006), 274-319.

48. Lettre de Géza Moravcsik à Zágon, Budapest, le 26 février 1912 (H-Bn, Département des Manuscrits, Fond XII/777).

49. Nagy, A Ferencz József koronázási jubileum-díj, 201-202.

50. Fövárosi Közlöny 23/33 (1912. április 26), 1526.

51. V. P., «Piano », Revue musicale S.I.M. 8/12 (décembre 1912), 67. 
qu'il ait fait une demande à Miklós Bánffy, l'intendant de l'Opéra, pour offrir sa traduction du livret de la cantate qu'il avait fait l'an précédent pour l'Orchestre de l'Académie, et qu'il aurait voulu recevoir une commande pour traduire le texte d'autres œuvres vocales françaises. En outre, Merkler fait mention de l'opéra en préparation de Zágon, dont la création à l'Opéra de Budapest lui paraît avoir de bonnes chances de se réaliser. ${ }^{52}$ Zágon travaillait donc déjà alors à la composition d'un opéra en français dont quelques scènes avaient déjà été écrites en juin 1913, mais dont seul un court fragment subsiste. ${ }^{53}$ Il avait demandé au poète Pierre Vierge (?-1944), son ami, d'écrire le livret en vers, car il avait l'intention, à l'instar des opéras d'inspiration symboliste du temps comme Pelléas et Mélisande de Debussy, de mettre en musique de la poésie, ayant une vraie valeur artistique. ${ }^{54}$

L'année 1913 et le début de la suivante furent pour Zágon une période particulièrement active et riche en événements. En avril, il publia dans Zeneközlöny son premier article de fond sur la vie musicale de Paris sous le titre «Zenei élet Párisban », pour continuer avec d'autres écrits, pleins de vie, dans lesquels il traitait, en tant que témoin initié, des spectacles marquants qui avaient eu lieu récemment. ${ }^{55}$ Il était absolument impressionné par la série de productions mémorables de la Saison Russe, dont les brillantes représentations d'opéras comme Boris Godunov et La Khovantchina ainsi que les spectacles des Ballets russes de Diaghilev, marqués par le concept d'œuvre d'art totale. Le Sacre du printemps, la nouvelle musique de ballet de Stravinsky, en particulier, exerça une influence déterminante sur Zágon lorsqu'il assista, le 29 mai 1913, à sa création mouvementée au tout nouveau théâtre des Champs-Élysées. Cette expérience artistique, dont il rapporta ses impressions d'abord à sa mère, ${ }^{56}$ devint un élément récurrent de ses écrits. Dans son article intitulé « Kubizmus a zenében » (Le Cubisme dans la musique), il est sans doute le premier à découvrir les analogies musicales du nouveau courant artistique dans les musiques de Bartók et de Stravinsky, et à démontrer entre elles une parenté spirituelle.

C'est également durant la dernière année de paix qu'il connut ses premiers grands succès de compositeur. Aux concerts de la Société Musicale Indépendante (S.M.I), destinés à promouvoir la présentation d'œuvres nouvelles, il eut la chance de créer deux de ses œuvres ; en octobre, il publia chez Mathot le premier secrétaire général de cette nouvelle société musicale, sa pièce pour piano Jeux de

52. Lettres d'Andor Merkler à Zágon, Budapest, le 11 et le 16 septembre 1912 (H-Bn, Département des Manuscrits, Fond XII/753).

53. H-Bn, Département de la Musique, Ms. mus. 2.020. Avec fragment du poème de Pierre Vierge, en manuscrit. Le poète envoya des vers à Zágon en mai 1914 à Budapest.

54. Lettre de Zágon en langue allemande à sa mère, Paris, 11 juin 1913 (H-Bn, Département des Manuscrits, Fond XII/1225).

55. «Zenei élet Párisban », Zeneközlöny 11/17 (1913. április 15.), 551-562; « Töredékek egy megíratlan naplóból », Zeneközlöny 11/18 (1913. május 15.), 607-615; « Kubizmus a zenében », Zeneközlöny 12/1 (1913. október 15.), 4-7; « A Théâtre des Champs-Elysées », Zeneközlöny 12/8 (1913. december 15.), 194-199.

56. Lettre mentionnée dans la note 54. 
vagues, dédiée à Imre Balabán, avec comme épigraphe un extrait d'un poème d'Émile Verhaeren.$^{57}$ Lors du concert du 22 mai à la salle de l'Ancien Conservatoire, il joua sa Sonate en ré bémol majeur dans sa forme définitive avec un second et dernier mouvement profondément retravaillé. (Cette version de la Sonate allait paraître l'année suivante chez Rózsavölgyi.) Au concert du 17 décembre à la Salle Pleyel, il créa son Pierrot lunaire avec la chanteuse Madeleine Bonnard qui remplaça Helda Roosevelt, tombée malade. Son cycle de mélodies reçut, de la part du chroniqueur des concerts du Comœdia, Émile Vuillermoz, un accueil très favorable :

Ces mélodies d'un des compositeurs les mieux doués de la jeune école hongroise, si vivante et si originale, sont d'un impressionnisme raffiné et d'une écriture très séduisante. Le charme bergamasque des visions d'Albert Giraud a été traduit par Zagon avec la plus fine sensibilité et la plus souple élégance. Un très vif succès en accueillit la révélation. ${ }^{58}$

Il en fut de même pour les critiques de la Revue musicale S.I.M. et du Monde musical. ${ }^{59}$ Compte tenu de cette réussite, c'est probablement la Grande Guerre qui fit échouer l'édition de cette composition, qui fut pourtant projetée par Mathot, en juin 1914, dans les mêmes conditions que pour les Jeux de vagues (Source 3).

Fondée à la fin de 1909 par Maurice Ravel et ses amis Charles Koechlin, Florent Schmitt, Émile Vuillermoz entre autres, la S.M.I. était considérée alors comme la société rivale de la Société Nationale (S.N.). Contrairement à la S.N. affiliée à la Schola Cantorum, d'orientation «nationaliste », la S.M.I. prenait appui sur les compositeurs d'avant-garde sortis du Conservatoire et accordait plus de place aux compositeurs contemporains étrangers. Jusqu'en 1914, l'école russe et espagnole dominait la programmation étrangère de la S.M.I. Ce n'est que bien plus tard que le comité invitera Bartók parmi ses membres. Seules quelques œuvres hongroises pouvaient être entendues dans les années 1910. Il est vrai que, dû au succès du festival hongrois, les Six Pièces pour piano (Zongoramuzsika) de Kodály figurait au programme du concert inaugural de la société ayant lieu le 20 avril 1910. Mais créée par Tivadar Szántó, l'œuvre reçut un accueil houleux, et pendant un certain temps, la musique contemporaine hongroise fut quasiment absente des concerts de la S.M.I. ${ }^{60}$ Peu avant la première exécution parisienne de la Sonate de Zágon cependant, deux œuvres hongroises récentes firent du bruit : la Suite de Miklós

57. Jeux de vagues : "Hullámjáték" pour Piano 2 mains (Paris : Éditions Littéraires et Musicales A. Z. Mathot - Leipzig : Breitkopf et Härtel - Bruxelles : J. B. Katto, 1913).

58. Émile Vuillermoz, « La Musique au Concert », Comœdia 22 décembre 7/2273 (22 décembre 1913), 5.

59. Jean Poueigh, « A travers la quinzaine », Revue musicale S.I.M. 10/1 (1 janvier 1914), 50. ; Laurent Ceillier, « S.M.I. », Le Monde musical 25/24 (30 décembre 1913), 364. La critique parue dans Le Monde musical est mentionnée par Zágon dans sa lettre du 6 janvier 1914 à sa mère. (H-Bn, Département des Manuscrits, Fond XII/1225).

60. Seules quelques-unes des œuvres de Tivadar Szántó, pianiste et compositeur vivant alors à Paris, furent programmées çà et là. 
Radnai et surtout, la Sonate pour violoncelle et piano opus 4 de Zoltán Kodály. La pièce de Kodály, quant à elle, remporta un grand succès au concert du 3 mai 1913 et devint très populaire parmi les musiciens de Paris, en dépit de l'interprétation, qualifiée d'un peu rigide par les critiques et de problématique selon Zágon luimême, du pianiste Alfredo Casella et du violoncelliste Diran Alexanian (Sources 4.1-4.). ${ }^{61}$ Et peu après la création du Pierrot lunaire, en février 1914, deux autres nouveautés hongroises trouvèrent aussi un écho dans la presse française : le Trio de Miklós Radnai ainsi que la Ballade pour clarinette et piano de Leó Weiner, créée en Hongrie au dernier concert de l'UMZE. ${ }^{62}$

Il semble évident qu'en tant que sociétaire, à la fois résolu et zélé, et aussi grâce à sa relation avec Vuillermoz - un des fondateurs et membre du comité de la S.M.I. -, Zágon joua un rôle majeur dans la promotion des œuvres hongroises à la société au printemps de 1913 et pendant la saison suivante. En effet, pour qu'un compositeur puisse présenter son œuvre à un concert de la S.M.I., il était nécessaire d'adhérer d'abord à la société en payant une cotisation, et sa composition devait convaincre le comité responsable de la direction artistique. Le choix des œuvres à exécuter était une question sensible, d'autant plus que, faute de subvention, c'était généralement les membres prestigieux qui contribuaient financièrement à l'organisation des concerts. ${ }^{63}$ Comme en témoigne sa lettre à Kodály, datée du 3 mai 1913, Zágon avait remis à la S.M.I., quelques mois auparavant, les partitions de plusieurs œuvres hongroises, dont celle de la Sonate opus 4 pour violoncelle et piano de Kodály. L'intention initiale du jeune compositeur était qu'il joue lui-même toutes ces pièces à un seul concert : ce projet avorta malgré le soutien de Vuillermoz (Source 5). On peut, en outre, présumer que son « protecteur » soit aussi intervenu dans le débat dont les deux Pierrot lunaire faisaient l'objet au sein du comité. C'est que la décision favorable à Zágon fut prise en dépit du fait qu'un contrat avait déjà été conclu pour présenter le mélodrame de Schönberg, et son cycle de mélodies était d'abord laissé de côté à cause de son titre identique. ${ }^{64}$

À côté de Vuillermoz, Louis Laloy se rangeait aussi parmi les premiers partisans français de la nouvelle musique hongroise. Il était, en ce temps-là, metteur en scène du Théâtre des Arts et écrivait des livrets de ballet pour ses productions de haut niveau artistique. Lorsque, au printemps 1913, il s'adressa à Zágon pour qu'il recommande un ballet de la jeune école hongroise, court et pittoresque, « dont la

61. Pour cela, voir la lettre de Zágon à Kodály, du 3 mai 1913 (source 4.1), ainsi que les critiques du Courrier Musical 16/12 (1 juin 1913) et celle du Monde musical 16/11 (15 mai 1913), que, d'ailleurs, Zágon joignit à sa lettre du 9 juin 1913. Les sources en langue hongroise sont aussi publiées en français, dans notre traduction.

62. Compte rendu sur la pièce de Radnai dans le numéro du 15 février 1914 de la Revue musicale S.I.M. Sur l'œuvre de Weiner créée le 25 février 1914, voir Le Guide du concert et Le Guide musical (données de Michel Duchesneau, « Maurice Ravel et la Société Musicale Indépendante : "Projet mirifique de concerts scandaleux" », Revue de Musicologie 80/2 (1994), 280.) Écho dans la presse hongroise : Pál Aranyossy, « Az új magyar zene Párizsban », Zeneközlöny 12/18 (1914. április 15.), 467-468.

63. Duchesneau, « Maurice Ravel et la Société Musicale Indépendante », 260.

64. Lettre de Zágon à Bartók, Paris, le 26 avril 1913 (Dille, Briefe an Bartók, 21, 23.) 
musique ait une réelle valeur d'art », (Sources 6.1-2) celui-ci eut recours à Bartók : il lui demanda de faire parvenir les partitions des Deux danses roumaines, des Deux images et de la série Gyermekeknek. ${ }^{65}$ Bien que les partitions soient arrivées trop tard et que la représentation n'eût pas lieu, Zágon joua les pièces à Laloy qui appréciait particulièrement la série Gyermekeknek. ${ }^{66}$ D’ailleurs, Bartók concentrait alors ses efforts sur ses recherches en musique folklorique, et notamment, sur son voyage de collecte à Biskra en Algérie, projeté pour l'été : c'est pour cela qu'il demanda et reçut de l'aide de Zágon. ${ }^{67}$ Pendant sa retraite de presque une année, il ne s'enthousiasmait guère à l'idée de faire connaître sa musique à l'étranger. Ainsi le plan de Zágon consistant à organiser à Paris, à la manière du festival hongrois, des manifestations musicales réunissant plusieurs compositeurs hongrois, tourna court. Bartók, à qui il en parla le premier, refusa sa requête en tant que victime du monde musical officiel dans une lettre désormais célèbre du 22 août 1913 à Vésztő. ${ }^{68}$ De même, Jenő Hubay et Pongrác Kacsoh donnèrent, en septembre, une réponse évasive et défavorable aux propositions de Zágon (Sources 7 et 8 ).

Parmi les relations parisiennes de Zágon, c'est sans doute à Michel-Dimitri Calvocoressi, le grand connaisseur et propagateur des mouvements musicaux d'avant-garde, que la nouvelle musique hongroise doit le plus, ayant fait connaître à l'étranger ses chefs de file - encore entravés dans leur pays et renfermés sur eux-mêmes pour des raisons socio-culturelles - en même temps que Stravinsky et Schönberg. Comme en attestent les lettres de Calvocoressi à Zágon ainsi que la correspondance de ce dernier avec Kodály et Bartók, ce fut Zágon qui attira l'attention de ce personnage influent sur la nouvelle musique hongroise. Il lui fit connaître, à côté de ses propres compositions, la série Gyermekeknek de Bartók, la Sonate opus 4 et de nombreuses mélodies de Kodály, ainsi que bien d'autres œuvres qui ne sont pas directement mentionnées dans les lettres, mais qui figurent dans les écrits de Calvocoressi ou encore, au programme des concerts suivant ses conférences.

Le premier témoignage de leur rencontre est un billet du 23 février 1913, dans laquelle le musicologue et critique musical d'origine grecque remercie Zágon pour les partitions envoyées et l'invite chez lui (Source 9.1). Dans le numéro spécial de juin 1913 du Comcedia illustré, consacré aux Ballets Russes, c'est déjà en tant qu'expert que Calvocoressi s'occupe, au sein de la chronique des concerts, de la nouvelle école hongroise qui est, selon lui, la plus jeune en Europe et l'une des

65. Lettre de Zágon à Bartók, Paris, le 1 avril 1913. (Dille, Briefe an Bartók, 18-20.)

66. Lettre de Zágon à Bartók, Budapest, le 23 juin 1914. (Dille, Briefe an Bartók, 26.)

67. Concernant le voyage de collecte de Bartók en Algérie, les lettres originales de Bartók (avril, 3 mai, 19 juin 1913) sont conservées par le Département des Manuscrits de la H-Bn (Fond XII/62) ; celles-ci ont été publiées par Demény, Bartók Béla levelei, 202-203, 205-206, 207 ; les lettres de Zágon relatives (26 avril, 27 mai, 24 juin 1913) sont publiées par Dille, Briefe an Bartók, 20-27 ; l'original de la lettre du 24 juin provient du legs Zágon (H-Bn Département des Manuscrits, Fond XII/1224).

68. H-Bn, Département des Manuscrits, Fond XII/62. Publiée par Demény, Bartók Béla levelei, 208-209. La lettre de Zágon à Bartók ne se retrouve pas dans les Archives de Bartók. 
plus intéressantes. Après avoir commenté les deux œuvres hongroises qui eurent du succès aux derniers concerts de la S.M.I., il évoque les exécutions de la Zongoramuzsika de Kodály, du Quatuor de Bartók et de la Suite de Miklós Radnai qui eurent lieu précédemment, en faisant allusion même à des compositions de Bartók et de Kodály, encore en manuscrit, qu'il eut l'occasion d'étudier et que le public connaîtra bientôt. Pour accompagner sa chronique, il publie une photo d'une demi-page de Zágon et commente sa Sonate, qu'il n'entendit que lors d'une exécution privée. ${ }^{69}$ Avec l'aide de Zágon, Calvocoressi devint bientôt un fin connaisseur de la musique hongroise contemporaine. Ainsi, en août, dans une carte postale à Zágon envoyée d'Oxford, il indique qu'il donnera une conférence sur ce thème en Irlande (Source 9.2). Dans son article paru dans un numéro d'automne du Musical Times, présentant une vue d'ensemble sur la lignée des compositeurs contemporains d'inspiration populaire, on peut relever les noms des musiciens folkloristes hongrois, et, parmi les exemples musicaux, des extraits tirés de la série Gyermekeknek. ${ }^{70}$

Il est plus ou moins connu que Zágon donna aussi à Calvocoressi, en tant que pianiste, un précieux coup de main pour ses conférences ayant trait entre autres à la nouvelle musique hongroise. Celles-ci furent tenues, du moins en partie, à l'École des Hautes Études Sociales dans le cadre du cours «Études d'Analyse musicale » lors de l'année académique 1913-1914, et faisant partie d'un ensemble sur quelques tendances de la musique contemporaine. Le 23 janvier 1914, Zágon joua des pièces de la série Gyermekeknek et le cycle Esquisses (Vázlatok) de Bartók, ainsi que certaines pièces de la Zongoramuzsika de Kodály. Au cours du concert du 30 janvier, il interpréta l'une des Danses roumaines de Bartók et sa Sonate en ré bémol majeur. ${ }^{71}$ La lettre de remerciement de Calvocoressi à Zágon laisse à penser que l'œuvre de Zágon remporta de nouveau un beau succès. Par la suite furent probablement programmées les mélodies de Kodály que le jeune compositeur avait proposées et traduites en français, ${ }^{72}$ et aussi la Sonate opus 4 du même, car dans une de ses lettres, Calvocoressi demanda à Zágon de donner un grand concert en deux parties (Sources 9.3-5). Enfin, c'est grâce à Zágon que, en lien avec ses collectes effectuées à Biskra, Bartók se mit en contact direct avec Calvocoressi en

69. Michel-Dimitri Calvocoressi, « Aux concerts », Comødia illustré 7/2073 (5 juin 1913), 830-831.

70. Idem, «Folk-Song in Modern Music », The Musical Times 54/849 (1 November 1913), 718.

71. Voir le programme manuscrit de ces auditions musicales sur papier à en-tête de l'École des Hautes Études Sociales (Archives de Kodály, fonds Zágon). Notons que ce document fournit la date de la création des Esquisses longtemps ignorée. Concernant ces concerts, le critique de la Revue musicale S.I.M. s'exprime ainsi : « M. V. G. Zagon défend avec un louable zèle la jeune école hongroise dont il fait d'ailleurs partie. Bartock [!] et Kodaly sont exprimés par lui avec une compréhension totale. », voir le numéro du 15 février 1914, p. 9. Écho dans la presse hongroise : Pál Aranyossy, « Az új magyar zene Párizsban », Zeneközlöny 12/18 (1914. április 15.), 467-468. Zágon joua quelques pièces de la Zongoramuzsika le 7 mars 1914 aussi à Paris, voir Mária Nyéki, « Kodály et la France », Cahiers d'Etudes Hongroises 2 (1990), 100.

72. Mélodies énumérées dans la lettre de Zágon à Kodály, Paris, le 9 juin 1913 (source 4.2). 
mai 1914 (et à travers lui avec l'ethnomusicologue Julien Tiersot), et qu'une rencontre personnelle eut lieu entre eux en été de la même année (Source 9.6).

L'éclatement de la guerre mondiale, suivi de l'incorporation de Zágon dans l'armée et finalement sa mort mirent un terme à la continuation de sa fructueuse coopération avec l'excellent musicologue, ainsi qu'à d'autres de ses projets par exemple sa participation au groupe de travail préparatoire du comité folklorique, décidé par le Congrès musical international de Paris. ${ }^{73}$ Le service militaire étant inévitable, il rejoignit, en tant que volontaire, l'artillerie de l'armée austro-hongroise qui nécessitait la plus longue formation ; son chef fut le lieutenant Ödön Márffy ${ }^{74}$ peintre, ayant étudié et longtemps vécu à Paris. Pendant la première année et demie de la guerre, il pouvait ainsi demeurer souvent chez lui à Budapest ${ }^{75}$ et même par la suite comme officier d'instruction ou comme blessé, selon les mémoires d'Antal Molnár. Il alla au front en février 1916 au plus tard, encore en tant qu'élève officier aspirant, avec la compagnie de marche 24/21 de la $5^{\mathrm{e}}$ brigade de marche. Incorporé au $32^{\mathrm{e}}$ régiment impérial-royal d'infanterie (celui de Budapest), ${ }^{76}$ il était, dans un premier temps, en instruction à l'arrière du front. Son régiment était alors en position sur le front de l'Est en Galicie, et c'est là qu'il subit l'offensive de Brusilov à partir de juin 1916. En janvier 1917 l'unité, dont le commandement fut pris par le lieutenant-colonel Ottó Redlich, se rendit en Transylvanie, ensuite, à travers la Bucovine, derrière les Carpathes. ${ }^{77}$ C'est en l'honneur de Redlich, le dernier et le plus connu des commandants du régiment, que Zágon composa la Marche militaire $d u 32^{\mathrm{e}}$, dans le texte de laquelle il inclut les grands combats que le régiment avait affrontés jusqu'au temps de la composition. ${ }^{78}$ Lorsqu'après une blessure, en automne 1918, il rejoignit de nouveau son équipe, le régiment combattait sur le front italien près de Combai, dans la région Veneto. À cause des conditions sanitaires provoquées par la guerre de tranchées et de graves difficultés de ravitaillement que l'armée austro-hongroise rencontra au moment de son effondrement, ${ }^{79}$ Zágon tomba malade et mourut, le 21 octobre 1918, dans l'ambulance $\mathrm{n}^{\circ} 1505$ à Follina. ${ }^{80} \mathrm{Il}$ avait vingt-neuf ans. Il fut probablement enterré à proximité de l'établissement hospitalier, ainsi sa tombe se trouve

73. Lettre de Zágon à Bartók, Budapest, le 23 juin 1914. (Dille, Briefe an Bartók, 25-26.)

74. Lettre d'Ede Telmányi à Zágon, envoyée à son adresse de Budapest, datée de Charlottenburg, le 28 mai [1915]. (H-Bn, Département des Manuscrits, Fond XII/1111).

75. En septembre 1915, il négocia encore personnellement avec Jenő Hubay. Voir la lettre de Hubay à Zágon, du 17 sept. 1915, envoyée à son adresse de Budapest. (H-Bn Département des Manuscrits, Fond XII/443).

76. Lettre de la mère de Zágon (Zsigmondné Zerkowitz) à Kodály, Budapest, le 12 février 1916 (KA/ Zágon-epist 5).

77. Budapest volt házi ezredének, a cs. és kir. 32. gyalogezrednek története, 1741-1918, éd. Sándor Tinódi Varga (Budapest : Pallas, 1930), 324-325, 241-250.

78. Redlich-induló : A 32-esek hadi indulója, szövegét és zenéjét írta Zágon Géza Vilmos=RedlichMarsch : Kriegsmarsch der 32-er, Text und Musik von Wilhelm Géza Zágon (Budapest-Lipcse : Rózsavölgyi és Társa, 1917).

79. Tinódi (éd), Budapest volt házi ezredének, 306-308.

80. Voir ses actes de décès dans les Archives de la Ville de Budapest (HU BFL-VII.12.b-1922-190767). 
aux alentours du bâtiment nommé aujourd'hui Casa di Riposo S. Giuseppe et du Sanctuaire militaire austro-hongrois érigé à la mémoire des quelques 900 soldats autrichiens, hongrois et d'autres nationalités qui y furent ensevelis. ${ }^{81}$

Sa mort prématurée lui enleva la chance d'un véritable épanouissement artistique, aussi bien que celle d'être reconnu dans son pays. Dans une atmosphère d'après-guerre très différente tant au plan politique que culturelle, les camarades survivants, dont les musicologues et critiques musicaux établissant le culte de Bartók et de Kodály, n'attachaient pas d'importance à la préservation de la mémoire du compositeur francophile, ainsi son œuvre de modeste dimension tomba dans l'oubli. Certes, grâce aux chercheurs travaillant sur Debussy et Bartók, certains de ses écrits, qui sont des témoignages sensibles de l'esprit de l'avant-garde, connurent un meilleur sort, mais une partie importante de sa production musicographique est presque restée inaperçue jusqu'à récemment. ${ }^{82}$ L'objectif principal de cette étude était de démontrer que l'œuvre de Zágon, même restée inachevée, mérite pleinement notre attention pour la raison aussi que le jeune musicien joua un rôle actif et significatif dans la vie musicale de son temps. Comme en attestent les lettres ci-dessous, Zágon agit - grâce à l'estime dont il jouissait de son vivant -, comme un intermédiaire efficace entre les cercles musicaux d'avant-garde hongrois et français : les relations qu'il forgea s'avéraient durables, et même, elles s'approfondirent après la guerre. De par la propagation des œuvres de Bartók et de Kodály, de par ses succès en tant que compositeur et ses qualités de pianiste, Zágon a largement contribué à la reconnaissance en France de la nouvelle musique hongroise, à peine sortie de l'ombre alors, et par là indirectement, à sa percée en Hongrie.

81. Informations recueillies sur le site internet de la ville, <http://www.comune.follina.tv.it/Storia/storia5. html>. (Date de consultation : 25 juillet 2014).

82. Quelques écrits et mélodies de Zágon sont étudiés dans le contexte du discours de l'époque sur la musique nationale hongroise par Lynn Hooker, Redefining Hungarian Music from Liszt to Bartók (Oxford : Oxford University Press, 2013). 


\section{Sources}

1.

Lettre de Claude Debussy à Géza Vilmos Zágon

Paris, le 22 janvier 1911

\section{H-Bn, Département des Manuscrits, Fond XII/199, Ep. Mus. 1236}

Lettre autographe signée à l'encre noire, en langue française, sur papier deuil, avec enveloppe. 1 folio (2 pages inscrites).

Monsieur Guillaume Zágon /V. Zoltán-utcza 11./à Budapest/ - Autriche-Hongrie -

$22-\mathrm{I} / 11$

Cher Monsieur,

Vous recevrez en même temps que cette lettre, votre "Pierrot-Lunaire" avec les corrections que j'ai cru devoir y apporter, qui, d'ailleurs, portent presque toutes sur des accents prosodiques.

Plus spécialement, je vous ferais remarquer la "tessiture" un peu forcée de "Messe rouge ${ }^{["]}$... La voix qui pourrait à la fois sonner au commencement et à la fin me semble difficile à trouver ? Peut-être y aurait-il profit à modifier la fin.

La musique qui décrit "Le départ de Pierrot" ne me paraît pas aussi heureusement trouvée que dans les autres pièces... Pour tout dire, elle est plus lunaire que pierrot. Il y a dans le poème, un mouvement, une fantaisie que l'on ne retrouve ${ }^{83}$ point dans votre musique. Vous devez, il me semble, trouver mieux ; et tout en conservant cette sorte de mélancolie lunaire, l'entourer de rythmes ${ }^{84}$ plus légers, plus impalpables.

Etant donné vos réelles qualités de musicien vraiment doué, vous ne devez pas, à mon avis, vous contenter d'un à peu près.

Avec mes compliments, croyez cher Monsieur, à mon meilleur souvenir.

Claude Debussy

83. Dans l'original : « retrouvent».

84. Dans l'original : « rhytmes ». 
2.

Lettre de Dezső Demény ${ }^{85}$ à Géza Vilmos Zágon

Budapest, le 25 janvier 1912

\section{H-Bn, Département des Manuscrits, Fond XII/204, Ep. Mus. 1227/a}

Lettre autographe signée à l'encre noire, en langue hongroise, sans enveloppe. 2 folios (3 pages inscrites).

Budapest, 1912. I. 25.

Kedves Zágon Úr!

Fölösleges munkát okozott önmagának levele írásával, hanem azért tagadhatatlanul nagyon örültem neki, mert általa a félreértés árnyéka is eloszlik az ügyről.

Engem a dologban nem maga a tény bántott, hogy t. i. quasi kényszeriteni akartak a nyilatkozat közlésére, hanem a körülmények. És pedig hogy három olyan munkatársamtól jött, akiknek módjukban állott az ilyen kérdésekben való elvi álláspontomat ismerni, mert azt éreztem belőle, hogy ez a három úr kételkedik azon, vajjon közlöm-e a nyilatkozatot, vagy sem. És tagadhatatlanul bántott egy ideig, és pedig azért, mert átlagban véve fütyülök arra, hogy X. Y-nak mi a véleménye rólam, de vannak emberek, akiknél súlyt helyezek rá, hogy ne legyenek rossz véleménnyel.

Miután pedig a dolgot így letárgyaltuk, térjünk napirendre s többet szó se essék róla.

Mostani kedves levelében foglalt nehány momentumra óhajtok még reflektálni.

Bizonyos fokú féltékenységgel vigyázok rá, hogy a Z. K-re senki se foghassa, hogy egy irány vagy kottéria szolgálatában áll. Egyéni fölfogásomat, hogy mindenkinek becsületes véleményét, még ha az enyémmel ellenkezik is, tiszteletben tartom, magában a lapban is igyekeztem mindig kifejezésre juttatni. Így került a lapba Isoz cikke s így jön az önöké is. Én dr. Kovács cikkét nem olvastam, nem is szólhatok hozzá. Egyről absolute meg vagyok győződve, hogy becsületes meggyőződésből és lelkesedéssel írta épp a magyar zeneszerzők érdekében, s azt is belátom, hogy mindenkiről nem írhatott. Tehát Buttykay és a többiek érzékenységét nem osztom. De nem tagadhatom azt sem el, hogy lehet valakinek a Kovács cikkében foglalt tendencia, a bartókizmus ellen kifogása. Isozt évek óta ismervén teljes határozottsággal merem állítani, hogy az a cikke Kovácsénál nem kevesebb ügyszeretettel, lelkesedéssel és jó szándékkal íródott meg. A két cikk közötti ellentét azon két pólus között lévő áthidalhatatlannak tetsző űrből származik, mely azon két muzsikális irányzat között van, melyeket ez a két úr képvisel, illetőleg a melyért ők ketten külön-külön lelkesednek.

85. Dezső Demény (1871-1937) - compositeur, chef de chœur, ecclésiastique, fondateur et rédacteur de la revue Zeneközlöny. 
Az önök nyilatkozata óta ismételten átolvastam az Isoz féle cikket és arról is csak azt tudom konstatálni, hogy sértő benne nem foglaltatik, ha csak azt nem veszik sértésnek, hogy nem mindenben osztja dr. Kovács felettébb subjectiv véleményét; vagyis azt konstatálom, amit önök állítanak Kovács dr. cikkéről.

NB. Éppen nem ijedek meg polémiáktól s mint ilyen polemikus válasz, az önök nyilatkozata csak kedves nekem; mert meg vagyok győződve, hogy a vélemények kifejtésére, új fogalmak alakulására és a régiek tisztázására ez a leghelyesebb és legjobb módszer.

Ami a nélkülözhetetlen működést illeti, arra vonatkozólag teljesen egy állásponton vagyok önökkel, h t. i. senki sem pótolhatatlan, sem önök, sem én, sem senki más a világon, még maga Beethoven sem. Meg vagyok győződve, hogy a Z. K. önök nélkül is megélne, de engedjék meg kijelentenem, hogy az önök viszszavonulása mégis csak visszafejlődést jelentene s nagy veszteséget a lapra s az egész közönségre. Vagyis más szóval számítok rá, hogy a lap mellett a jövőben is kitartanak úgy, mint eddig, sőt - ha szabad kérnem - még az eddiginél is intenzívebb módon. Ha egymás részéről tapasztalunk valami nekünk nem kedves dolgot, őszintén és nyíltan mondjuk meg. Így lehet tisztázni legjobban a helyzetet. Clara pacta, boni amici!

Ezek után, elmondván mindent, amit az esetből kifolyólag mondani akartam, kérem Önt kedves Zágon Úr, adja át társainak az én igaz tiszteletem kifejezését és fogadja saját személye számára is.

Baráti kézszorítással

maradtam
öszinte híve
Demény Dezsö

Cher Monsieur,

Vous vous êtes causé un travail inutile en écrivant votre lettre, mais il n'y a pas à nier que j'en étais très content, car elle vient dissiper même l'ombre d'un malentendu.

Ce qui m'a blessé dans cette affaire n'est pas le fait même, c.-à-d. que vous vouliez quasiment me forcer à publier votre déclaration, mais ce sont les circonstances. À savoir que cela est venu de trois de mes collègues qui étaient en mesure de connaître ma position de principe que je prends dans telles questions, parce que j'avais l'impression que ces trois messieurs doutaient de ce que je publie vraiment la déclaration ou pas. Et il n'y a pas à nier que cela m'a blessé pendant un certain temps, et ce parce qu'en général, je me fous de savoir ce que $X$. Y. pense de moi, mais il y a des gens chez qui je tiens à ce qu'ils n'aient pas une mauvaise opinion de moi. 
Après avoir réglé ainsi cette affaire, passons outre et n'en parlons plus.

Je souhaite encore réagir à quelques points de votre lettre.

C'est avec une certaine jalousie que je prends garde au Z. K., afin que personne ne puisse lui imputer d'être au service d'un courant ou d'une coterie. J'ai toujours essayé de manifester, dans le journal même, mon point de vue personnel c'est que je respecte l'honnête opinion de tout le monde, même si elle est contraire à la mienne. C'est comme cela que l'article d'Isoz a vu le jour dans le journal et c'est comme cela que le vôtre viendra. Quant à l'article de dr. Kovács, je ne l'ai pas lu, donc je ne peux pas donner mon avis là-dessus. Mais une chose dont je suis absolument convaincu, c'est qu'il l'avait écrit avec une conviction et un enthousiasme honnête justement en faveur des compositeurs hongrois, et je reconnais aussi qu'il ne pouvait pas écrire de tout le monde. Donc je ne partage pas la sensibilité de Buttykay et des autres. Mais je ne peux pas nier non plus que la tendance implicite de l'article de Kovács, le bartókisme, peut soulever des objections. Connaissant Isoz depuis des années, j'ose affirmer avec une certitude absolue que son article a été écrit avec non moins de zèle, enthousiasme et de bienveillance. La différence fondamentale entre les deux articles réside dans le fait qu'il y a un abîme qui paraît infranchissable entre ces deux pôles, c.-à-d. entre les deux courants musicaux que ces deux messieurs représentent et pour lesquels ils s'enthousiasment respectivement.

Depuis votre déclaration, j'ai relu l'article d'Isoz et là aussi je peux constater qu'il n'a rien d'offensif, sauf si vous prenez pour une insulte le fait qu'il ne partage pas en tout point l'opinion très subjective de $d r$. Kovács ; $c$-à-d. je constate la même chose à propos de ce que vous affirmez sur l'article de dr. Kovács.

$N$.B. Soyez sûrs que je ne flanche pas face aux polémiques, et qu'en tant qu'une telle réponse polémique, je tiens à votre déclaration; car je suis convaincu que c'est la meilleure et la plus correcte méthode pour exposer les opinions, créer de nouveaux concepts et éclaircir des anciens.

En ce qui concerne le fonctionnement indispensable, j'ai exactement le même point de vue que vous, à savoir que personne n'est irremplaçable, ni vous, ni moi, ni aucun autre dans le monde, ni Beethoven même. Je suis convaincu que le Z.K. pourrait se passer de vous, mais permettez-moi de vous dire sans ambages que votre retraite signifierait un recul quand même, et une grande perte pour la revue et pour tout le public. Autrement dit, je compte sur votre engagement et contribution au journal dans l'avenir aussi, de la même manière que jusqu'à présent, voire même - si je peux demander - de manière plus intense encore. Si on éprouve, l'un envers l'autre, quelque chose qui nous est désagréable, disons-le franchement et ouvertement. C'est la meilleure voie pour démêler la situation. Clara pacta, boni amici! 
Cher Monsieur, je crois avoir dit tout ce que je voulais sur le cas. Je vous prie d'agréer l'expression de mes sentiments respectueux et de le transmettre à vos camarades aussi.

En vous serrant amicalement la main

je reste
votre tout dévoué
[Dezsö Demény]

3.

Lettre d'Albert Zunz Mathot à Géza Vilmos Zágon

Paris, le 15 juin 1914

H-Bn, Département des Manuscrits, Fond XII/740.

Lettre dactylographiée avec signature autographe, en langue française, sur papier à en-tête :

« A. Z. Mathot, Éditions Littéraires et Musicales, 11, Rue Bergère. Paris », avec enveloppe.

2 folios (2 pages inscrites).

Paris, le 15 Juin 1914

Monsieur V. G. ZAGON

V. Zoltán utca 11-BUDAPEST

Cher Monsieur,

Je reçois votre lettre de Samedi et m'empresse d'y répondre.

Je ne crois pas pouvoir proposer à mes commanditaires l'édition de cette œuvre à d'autres conditions que celles faites pour la publication de vos «JEUX DE VAGUES ». Si ceci peut vous convenir, je serai enchanté de donner l'hospitalité à votre «PIERROT LUNAIRE » qui, vous le savez, m'a laissé la meilleure impression. Au cas où vous seriez d'accord il faudrait que vous ayiez l'obligeance de m'envoyer le manuscrit accompagné d'une lettre semblable à celle que vous m'avez écrite pour vos «JEUX DE VAGUES »; je vous en adresse du reste le texte sous ce pli, de manière que, le cas échéant, vous n'ayez qu'à signer.

Je ne pourrai naturellement vous fixer le prix du recueil qu'après avoir revu le manuscrit.

Agréez, cher Monsieur, l'assurance de mes sentiments très distingués.

A. Z. Mathot 
Inclus: 1 texte

Paris, le 15 Juin 1914

Monsieur A. Z. MATHOT

Editeur

11 Rue Bergère. PARIS.

Monsieur,

Comme suite à notre conversation, je vous confirme que si vous voulez bien publier mon recueil intitulé «PIERROT LUNAIRE », je m'engage à vous en faire acheter cinquante exemplaires au prix marqué, dans le mois qui suivra la publication de cette œuvre.

Si contrairement à mon attente, les commandes n'atteignaient pas le délai stipulé, le chiffre de 50 exemplaires, je complèterais ce chiffre en achetant moimême le nombre d'exemplaires nécessaire.

Agréez, Monsieur, l’assurance de mes sentiments distingués.

4.1.

Lettre de Géza Vilmos Zágon à Zoltán Kodály

Paris, le 3 mai 1913

\section{Archives de Kodály, KA/Zágon-epist. 1}

Lettre autographe signée à l'encre noire, en langue hongroise.

2 folios (3 pages inscrites).

Páris, 1913. május 3.

Igen tisztelt Tanár Úr,

néhány hónapja több magyar kompozícióval együtt az Ön szonátáját is beadtam a Société Indépendante-hoz. Úgy volt tervezve, hogy a magyar müvek egy estén kerülnek előadásra; minthogy a saját dolgaimat úgy is én játszom, ajánlkoztam a többi müvek interpretálására is, ismervén a szerzők és speciálisan az Ön intencióit. Minderről Vuillermoz-val, a comité tagjával és a S.I.M. főszerkesztőjével ismételten beszéltem. Azonban az eredeti tervet, miszerint a magyar müveket egy koncertba [sic!] csoportosítsák, elejtették, és az Ön szonátáját tudtomon kívül a mai, első koncertra tüzték ki; a programmon olvashatók az előadók nevei. Erre a dologra vonatkozólag megírtam véleményemet Vuillermoz-nak, és még személyesen is meg fogom neki mondani. 
Ott voltam a koncerton és az előadásról sajnos semmi jót sem mondhatok; sőt éppen ellenkezőleg. De hát én sem tehetek róla, ha rajtam múlik, bizonyára másképp sikerült volna. Mindenesetre értesíteni akartam Önt az ügyről. Calvocoressi, aki mostanában behatóan foglalkozik az új magyar zenével, szintén jelen volt; neki legközelebb külön meg fogom mutatni a szonátát. Az eredeti kézirat, valamint a magyar dalok kéziratai nálam vannak és Tanár Úr természetesen bármikor diszponálhat felettük. Nincs kizárva azonban, hogy a dalokra előbb-utóbb még szükségem lehet valamiképpen; (az Umze-ban előadottakból van kópiám).

Fogadja, igen tisztelt Tanár Úr, legszivélyesebb üdvözleteimet.

Igaz híve

Zágon Géza Vilmos

Très honoré Professeur,

Il y a quelques mois, j'ai remis votre sonate, avec plusieurs autres compositions hongroises, à la Société Indépendante. Le plan était de programmer les auvres hongroises dans une même soirée ; en tant qu'interprète de mes propres pièces, je me suis offert pour jouer les autres auvres aussi, connaissant les intentions des auteurs et spécialement les vôtres. J'en ai discuté plusieurs fois avec Vuillermoz, membre du comité et rédacteur en chef de la S.I.M. Cependant, le projet original de regrouper les ouvres hongroises en un même concert a été rejeté, et votre sonate était inscrite, à mon insu, au premier concert, celui d'aujourd'hui ; vous trouverez les noms des interprètes sur le programme. À cet égard, j'ai écrit à Vuillermoz pour lui exprimer mon opinion, et je le lui dirai encore personnellement.

J'ai assisté au concert et ne peux malheureusement rien dire de bien sur l'interprétation ; c'est justement le contraire. Mais je n'y peux rien, si cela dépend de moi, elle réussit sans doute autrement. En tout cas, je voulais vous mettre au courant. Calvocoressi, qui étudie en ce moment la nouvelle musique hongroise d'une manière approfondie, était également présent ; la prochaine fois, je vais lui montrer spécialement votre sonate. Le manuscrit original en est chez moi, avec ceux des mélodies hongroises, et vous pouvez évidemment en disposer à tout moment. Il n'est pourtant pas exclu que, tôt ou tard, j'aurai besoin des mélodies pour quelque raison ; (j'ai une copie de celles présentées à l'UMZE).

Recevez, très honoré Professeur, mes salutations les plus cordiales.

Votre dévoué

[Géza Vilmos Zágon] 


\section{2. \\ Lettre de Géza Vilmos Zágon à Zoltán Kodály}

Paris, le 9 juin 1913.

\section{Archives de Kodály, KA/Zágon-epist. 2}

Lettre autographe signée à l'encre bleue, en langue hongroise, avec suppléments imprimés ${ }^{86} 2$ folios (4 pages inscrites).

Páris, 1913. jún. 9.

Igen tisztelt Tanár Úr,

kérem ne vegye rossz néven, hogy ily soká várattam válaszomra, de közben nagyon sok dolgom akadt. A mai póstával küldöm a cselló-szonáta kéziratát és mellékelek egy angol újságot, amelyet Calvocoressi küld Önnek.

Annak a példánynak, amelyből a Szonátát itt játszották, a története a következő:

Midőn a szonátát Budapesten játszani akartam, Önnek nem volt példánya, a kéziraton kívül. Erre én Berlinből, a magyar triótól küldettem el az ő példányukat magamnak, és írattam egy új példányt, a saját költségemre és természetesen azzal a célzattal, hogy ezt megőrizzem a magam számára, ami ellen Önnek bizonyára nem lesz kifogása. A berlini példányt azután visszaküldöttem Zsigmondy Gábornak. Bizonyára nála van még, és ezért kérem, tessék hozzáfordulni, a címe: I. Kelenhegyi-út 33. Itt tehát az én példányomból játszották a szonátát; ezt meg most egy időre Calvocoressi-nek adtam.

Casella úr üzeni Önnek, hogy rendkívül érdekelte a szonátája, és nagy öröme tellett benne, hogy játszhatta; kéreti Önt, ha lehetséges, juttasson neki egy példányt.

M. Ecorcheville-lel nem beszélhettem, mivel mostanában Berlinben volt; de a napokban felkeresem, és feltéve, hogy általa megszerezhetném a szonáta egy példányát, odaadhatom-e vajjon Casella úrnak? Mert bárminő legyen is az én személyes véleményem az ő interpretálásáról, azt hiszem, zenei körökben az ő szavára adnak valamit.

Kéziratban a köv. dalok vannak nálam:

„Akkor szép az erdő"

„Tudtad, tudtad, még sem mondtad"

„Körtéfa”

„Csak aztat csudálom”

„Vékony a pókháló”

86. Les supplémements sont les suivants : 1 . Projet de programme pour le cours «Études d'Analyse musicale » à l'École des Hautes Études Sociales (1913-1914) 2. Coupures de presse du Monde musical (15 mai 1913) et du Courrier musical (1 ${ }^{\text {er }}$ juin 1913). 
A többi, ami nálam van, másolat. Calvocoressi-nél vannak most „Akkor szép az erdő”, „Mezei dal”, „Azt gondolod, hogy én bánom”, „Tudtad, tudtad”. T.i. jövo évben conférence-ot akar tartani a magyar zenéről az École des hautes études sociales-ban, és ott az Ön dalait is énekelnék. Én fordítom őket franciára prózában, Calvocoressi alkalmazza a zenére. Minthogy kéziratokat gyűjt, Öntől is kér egyet; vajjon adhatok-e neki a dalok közül egyet, amelyikből van duplikátum (pl. Tudtad, tudtad)?

Bartók tanár úrnak már régebben írtam, hogy küldje el saját és az Ön fényképét Calvocoressi számára, mivel őneki szüksége volna ezekre. Nem tudom, szólt-e Önnek erről. Ha nem, kérném Tanár urat, legyen szíves eziránt intézkedni, és a képeket akár Calvocoressi-nek, akár nekem elküldeni. C. címe: M. D. Calvocoressi, 164, rue de Courcelles, Paris.

Mellékelten küldök két kritikát, amely a kezembe akadt.

Fogadja, Tanár Úr, legszívélyesebb üdvözleteimet, amelyekkel maradtam igaz híve

Zágon Géza Vilmos

Très honoré Professeur,

Veuillez m'excuser d'avoir tant tardé à vous répondre, mais j'ai été très occupé entre-temps. Je vous envoie avec ce courrier le manuscrit de la sonate pour violoncelle et piano et je joins un journal anglais que vous envoie Calvocoressi.

Voici l'histoire de l'exemplaire qui a servi ici pour jouer la Sonate:

Lorsque je voulais jouer la sonate à Budapest, vous n'aviez pas d'autre exemplaire que le manuscrit. Ainsi, je me suis fait envoyer l'exemplaire du trio hongrois de Berlin, et je me suis fait copier un nouvel exemplaire à mes propres frais et dans le dessein, bien sûr, de le garder pour moi-même ; j'espère que vous n'y verrez pas d'objection. Quant à l'exemplaire de Berlin, je l'ai fait renvoyer à Gábor Zsigmondy. Il est sans doute toujours chez lui, et donc, je vous prie de vous adresser à lui à : I. Kelenhegyi út 33. C'est donc mon exemplaire qui a été utilisé ici pour l'exécution de la sonate; mais je l'ai prêté à Calvocoressi pour quelque temps.

M. Casella me demande de vous dire que votre sonate lui tenait à coeur et qu'il a pris grand plaisir à la jouer ; il voudrait vous demander, si cela était possible, de lui faire parvenir un exemplaire.

Je ne pouvais pas parler à M. Ecorcheville car il était à Berlin récemment ; mais je vais lui rendre visite un de ces jours. À condition que, grâce à lui, je puisse me procurer un exemplaire de la sonate, est-ce qu'il m'est permis de le rendre à $M$. Casella ? C'est que, quelle que soit mon opinion personnelle sur son interprétation, je crois qu'il est très estimé dans les cercles musicaux.

J'ai ici les mélodies suivantes en manuscrit :

"Akkor szép az erdö» 
«Tudtad, tudtad, még sem mondtad»

«Körtéfa»

«Csak aztat csudálom»

«Vékony a pókháló »

Les autres que j'ai chez moi sont des copies. Les mélodies suivantes sont à présent chez Calvocoressi : "Akkor szép az erdö », "Mezei dal », "Azt gondolod, hogy én bánom », "Tudtad, tudtad». C'est que l'année prochaine, il a l'intention de faire une conférence, à l'École des hautes études sociales, sur la musique hongroise, et on voudrait y présenter vos mélodies aussi. Je les traduis en prose en français, et Calvocoressi fait l'adaptation musicale. Comme il collectionne les manuscrits, il vous en demande un de votre main : puis-je lui donner une des mélodies dont il y a un duplicata (par ex. Tudtad, tudtad)?

Il y a déjà un certain temps que j'ai écrit à monsieur le professeur Bartók pour qu'il envoie à Calvocoressi une photographie de lui-même et une de vous, car il en aurait besoin. Je ne sais pas s'il vous en a parlé. Sinon, je vous demande d'avoir la gentillesse de faire la démarche nécessaire pour envoyer les deux portraits soit à Calvocoressi, soit à moi. L'adresse de C. : M. D. Calvocoressi, 164, rue de Courcelles, Paris.

Je vous envoie ci-joint deux critiques qui me sont tombées sous la main.

Recevez, Monsieur le Professeur, mes salutations les plus cordiales.

Je reste votre tout dévoué

[Géza Vilmos Zágon]

4.3.

Lettre de Géza Vilmos Zágon à Zoltán Kodály

Paris, 26 janvier 1914

Archives de Kodály, KA/Zágon-epist. 3.

Lettre autographe signée à l'encre bleue, en langue hongroise.

1 folio (2 pages inscrites).

Paris, 1914. jan. 26.

3 , rue de l'Odéon

Igen tisztelt Tanár Úr!

E. R. Schmitz, ismert párisi muzsikus, kiváló zongorista és dirigens, aki egy nagy zenekari és énekkar-egyesület élén áll, ama kéréssel fordult hozzám, hogy szerezzek részére egy példányt az Ön cselló-szonátájából, előadás céljából. Kérem tehát Tanár Urat, juttasson számára egy példányt, ha módjában van, akár az ő címére: 3 Square du Champ de Mars, akár az enyémre. 
Még a tavasszal közöltem Bartók tanár úrral Calvocoressi ama kérését, hogy az Ön és a saját fényképét legyen szíves elküldeni. Bartók tanár úr meg is ígérte, hogy amint visszatér Algir-ból, elküldi. Mindeddig nem érkezett semmi, pedig Calvocoressi már több ízben sürgette. Kérem tehát, legyen szives ez ügyben is mielőbb intézkedni. Calvocoressi címe: 164, rue de Courcelles.

Szíves válaszát várom és kérem, fogadja igaz tiszteletem kifejezését, amellyel maradtam

kész híve

Zágon Géza Vilmos

Très honoré Professeur,

E. R. Schmitz, musicien parisien connu, excellent pianiste et chef d'orchestre, qui est à la tête d'une grande association orchestre et choeur, ${ }^{87}$ s'est adressé à moi pour obtenir un exemplaire de votre sonate pour violoncelle et piano en vue d'un concert. Je vous demande alors de lui faire parvenir un exemplaire, si vous êtes en mesure de le faire, soit à son adresse: 3 Square du Champ de Mars, soit à la mienne.

C'est encore au printemps que j'avais communiqué à monsieur le professeur Bartók la demande de Calvocoressi de lui envoyer une photographie de vous et une de lui-même. Monsieur Bartók a en effet promis de le faire dès qu'il rentre d'Alger. Or, rien n'est arrivé jusqu'à ce jour de sa part, malgré l'insistance répétée de Calvocoressi. Je vous prie alors de faire la démarche le plus tôt possible. L'adresse de Calvocoressi : 164, rue de Courcelles.

Dans l'attente de votre réponse, je vous prie d'agréer mes sentiments respectueux et

reste votre bien dévoué

[Géza Vilmos Zágon]

87. Elie Robert Schmitz (1889-1949) - pianiste et pédagogue musical français. Il dirigea l'« Association Musicale Moderne et Artistique » (en 1914 rebaptisée « Association de Concerts Schmitz ») de 1911 à 1914. 
4.4.

Lettre de Géza Vilmos Zágon à Zoltán Kodály

Paris, le 4 mars 1914

Archives de Kodály, KA/Zágon-epist. 4

Lettre autographe signée à l'encre bleue, en langue hongroise.

1 folio (2 pages inscrites).

Páris, 1914. márc. 4.

Igen tisztelt Tanár Úr,

a fényképekre publikálás céljából van szüksége Calvocoressinek, ami természetesen nem akadályozná meg őt, hogy személyesen is gyönyörködjék bennük. Kérem legyen szives mielőbb elintézni ezt a régóta huzódó ügyet.

A szonáta kéziratát Casella már csak azért sem kölcsönözhette Schmitz-nek, mivel ő maga is az én példányomat kérte kölcsön. T. i. az övét viszont Hekkingnek kölcsönözte, aki időközben hangversenykörúton volt, ő maga pedig, már t. i. Casella, a múlt héten is játszotta itt a szonátát valamilyen koncerton [sic!], az én példányomból. Amint ebből is kitűnik, a szonátát még korántsem únták meg, és sok víznek kell még lefolyni a Szajnán, amíg hozzáfoghatnak a megúnáshoz.

Bocsásson meg, ha kérdésem indiszkrét: hogyan lehetséges, hogy ez a szonáta még nincs meg nyomtatásban?

Visszakapván Casellától példányomat, megírtam Schmitznek, hogy rendelkezésére bocsájtom, ha még szüksége van rá.

Szivélyes üdvözlettel

igaz híve Zágon GV

Très honoré Professeur,

Calvocoressi a besoin des photographies en vue de les publier, ce qui ne l'empêcherait évidemment pas de s'en délecter personnellement aussi. Je vous demande de bien vouloir régler cette affaire qui traîne depuis longtemps.

L'une des raisons pour laquelle Casella ne pouvait pas prêter le manuscrit de la sonate à Schmitz est qu'il m'avait emprunté, lui-même, mon exemplaire. C'est que le sien, il l'avait à son tour prêté à Hekking qui effectuait entre-temps une tournée de concerts, et puis lui-même, c.-à-d. Casella a joué la sonate ici la semaine dernière aussi à quelque concert, avec ma partition sous le nez. Comme 
vous voyez, on ne s'est nullement encore lassé de la sonate, et il passera bien de l'eau sous les ponts de la Seine avant qu'on ne se mette à s'en lasser.

Pardonnez-moi si ma question est indiscrète : comment est-il possible que cette sonate n'ait pas encore été imprimée?

Ayant récupéré mon exemplaire de Casella, j'ai écrit à Schmitz que je le mettais à sa disposition, s'il en avait encore besoin.

Avec mes cordiales salutations

votre dévoué

[Géza Vilmos Zágon]

5.

Lettre d'Émile Vuillermoz ${ }^{88}$ à Géza Vilmos Zágon

Non datée [Paris, le 14 mai 1913] ${ }^{89}$

H-Bn Département des Manuscrits, Fond XII/1185, Ep. Mus. 1226.

Lettre autographe signée à l'encre noire, en langue française, sur le papier à en-tête de

« La Revue Musicale S.I.M., Mensuelle et Illustrée », avec enveloppe. 1 folio (1 page inscrite).

Monsieur Zagon / 3 rue de l'Odéon / Paris

Paris, le Mercredi

Cher Monsieur

Combien je regrette que vous ayez la malchance de vous adresser à celui des membres du Comité qui certainement a beaucoup moins de temps que tous ses camarades. J'ai dû laisser certaines de vos lettres sans réponse, mais soyez sûr que j'en ai toujours tenu compte de mon mieux. (En particulier pour l'affaire Casella-Kodaly où je n'ai pu triompher malgré une vive insistance.)

Pour le Guide du Concert (j'arrive de voyage), faites vite une notice et envoyez-la de suite avec cette carte pour qu'elle soit imprimée demain..$^{90}$

En hâte, mille bons souvenirs

E Vuillermoz

88. Émile Vuillermoz (1878-1960) - critique musical, musicographe et compositeur français, fervent partisan de la musique d'avant-garde, l'un des fondateurs et membre du comité de la Société Musicale Indépendante, rédacteur en chef de La Revue musicale S.I.M., ainsi que collaborateur musical de plusieurs journeaux, entre autres du Comodia et du Temps.

89. Daté d'après le cachet postal un peu effacé et le contenu.

90. Zágon a en effet rédigé la notice demandée, cf. Le Guide du concert 4/32 (17 mai 1913), 482. 


\section{1 .}

\section{Lettre de Louis Laloy ${ }^{91}$ à Géza Vilmos Zágon}

Paris, le 30 mars 1913

\section{H-Bn Département des Manuscrits, Fond XII/587, Ep. Mus. 1210/a}

Lettre autographe signée à l'encre noire, en langue française, sur le papier à en-tête du «Théâtre des Arts (Théâtre des Batignolles) », avec enveloppe.

1 folio (2 pages inscrites).

Monsieur Vilmos Géza Zágon / 3 rue de l'Odéon / Paris

$30 / 3 / 13$

Monsieur,

Je viens sur le conseil de $\mathrm{M}$. Vuillermoz m'adresser à vous pour la question suivante.

Nous désirerions donner, au mois de mai, au Théâtre des Arts, un ballet moderne, assez court (20 minutes environ), de caractère gai et pittoresque, enfin dont la musique ait une réelle valeur d'art. Nous avons pensé que la nouvelle école hongroise, que je fus l'un des premiers à apprécier à Paris, serait peut-être en état de nous fournir cet ouvrage. Je sais, Monsieur, que personne n'est mieux que vous à même de nous renseigner. Voulez-vous donc avoir la grande obligeance de fixer un rendez-vous par lettre ou téléphone à

M. Laloy 17 bis rue des Capucins

à Bellevue (Tél. 148)

ou ce qui serait mieux encore de prendre la peine de passer au Théâtre des Arts lundi dans l'après-midi, entre $2 \mathrm{~h} 1 / 2$ et 4 heures, et de me demander ? J'y serai, et nous pourrons causer.

Mille excuses, Monsieur, pour vous déranger ainsi, mais peut-être estimerez-vous que l'intérêt de l'art est une excuse en effet, et veuillez agréer l'assurance de mes très distingués sentiments.

91. Louis Laloy (1874-1944) - musicologue, écrivain et sinologue, professeur d'histoire de la musique à la Sorbonne, l'auteur de la première biographie de Debussy en 1909, fondateur du Mercure musical (qui deviendra plus tard La Revue musicale S.I.M.) et collaborateur de plusieurs organes de presse (Comødia, La Revue musicale, La Grande revue etc.). Il écrivit aussi des livrets de ballet pour le Théâtre des Arts, dirigé (à partir de 1910) par Jacques Rouché qui en fit une scène d’avant-garde. Zágon lui consacra un article (" Néhány szó Louis Laloy-ról ») dans Zeneközlöny où il publia également, dans sa traduction, son écrit « Les orgues de la Terre » (sous le titre « A Föld orgonái ») ; voir Zeneközlöny 13 (1915), 5., 67-68, 69-73. 


\section{2 . \\ Lettre de Louis Laloy à Géza Vilmos Zágon}

Paris, le 22 avril 1914

H-Bn Département des Manuscrits, Fond XII/587, Ep. Mus. 1210/b.

Lettre autographe signée à l'encre noire, en langue française, sur le papier à en-tête du « Comœdia, Journal Quotidien Illustré », avec enveloppe.

1 folio (1 page inscrite).

Monsieur V. G. Zágon / Zoltan utca 11 / Budapest / Hongrie ${ }^{92}$

Paris 1914. ápr. 22. [sic! $]^{93}$

Cher Monsieur,

Je suis empêché, à mon grand regret, de venir vous voir aujourd'hui. Pourriez-vous nous faire le grand plaisir d'une visite à Bellevue dimanche, l'après-midi vers $3 \mathrm{~h}$, ou le matin à $10 \mathrm{~h}$ si vous allez à un concert? Nous en serions très heureux et vous prions de croire à nos sentiments les meilleurs

Laloy

Bellevue 17 bis rue des Capucins

Tél. 148 
7.

Lettre de Jenő Hubay à Géza Vilmos Zágon

Budapest, le 22 septembre 1913

\section{H-Bn Département des Manuscrits, Fond XII/443, Ep. Mus. 1220/b.}

Lettre autographe signée à l'encre noire, en langue hongroise, avec enveloppe. 2 folios (2 pages inscrites).

Monsieur / Géza V. Zágon / 3 rue de l'Odéon / Paris / France ${ }^{94}$

Budapest, 1913. szept. 22.

II. Margit rakpart 11.

Igen tisztelt Zágon Úr,

Nem válaszolhattam eddig hozzám intézett szíves soraira, mert nem volt alkalmam az abban foglaltakat Mihalovich igazgató úrral megbeszélni. Végre tegnap találkoztam vele és értekezésünk eredményét azonnal közlöm Önnel.

Bármennyire kívánatos és örvendetes volna, ha a magyar zeneművészet érdekei Franciaországban, különösen Párisban nyomatékosan előmozdíttatnának s bármennyire a hajlandóság nálunk meg is volna e nem kicsinylendő mozgalom érdekében anyagi áldozatokat is hozni, addig nem lehet foglalkozni érdemlegesen az üggyel, míg egy írásba foglalt határozott és kötelezö propoziciót az ottani mérvadó körök részéről a miniszter úr elé nem terjeszthetünk.

Ha ez megtörtént, én kész örömmel a további lépéseket szívesen magamra vállalom.

Szívélyes üdvözlettel maradtam

igaz híve

Dr Hubay Jenő

Très honoré Monsieur Zágon,

Je ne pouvais pas vous répondre plus tôt car je n'avais pas eu l'occasion de consulter monsieur le directeur Mihalovich au sujet de cette affaire. Enfin, hier, je l'ai rencontré et me hâte de vous communiquer le résultat de notre entretien.

Quelque désirable et heureux qu'il soit de promouvoir avec vigueur les intérêts de l'art musical hongrois en France, et particulièrement à Paris, et quelque bien disposés que nous soyons à faire aussi des sacrifices financiers pour soutenir ce mouvement indépréciable, il n'est pas possible de traiter cette affaire sur 
le fond jusqu'à ce que nous ne puissions soumettre une proposition écrite, précise et obligatoire, de la part des cercles dirigeants de là-bas à monsieur le ministre.

Une fois cela fait, je serai prêt à assumer volontiers les démarches qui suivent. Avec mes cordiales salutations, je reste votre dévoué

[Dr Jenö Hubay]

8.

Lettre de Pongrác Kacsoh à Géza Vilmos Zágon

Budapest, le 19 septembre 1913

H-Bn Département des Manuscrits, Fond XII/493, Ep. Mus. 1216/b.

Lettre autographe signée à l'encre noire, sans enveloppe.

2 folios (4 pages inscrites).

Igen tisztelt Zágon Uram!

Köszönöm szíves és megtisztelő sorait. Ne vegye rossz néven, hogy propozíciójára határozottan nem-mel felelek.

Hitem az, hogy az olyan kommünikék, amelyeket csak egy anyagi ellenérték, hogy ne mondjam megalázó adó ellenében kapunk, mit sem használ a magyar zenének! Lássa kedves Zágon Uram, a Molnár Ferenc és Lengyel Menyhért darabjai bejárják a világot szubvencio és előfizetések nélkül. Nem hiszem, hogy a finnek adót fizetnének a francia nemzetközi zenetársaságnak, mégis Sibeliust és Järnefeltet az egész művelt világ ismeri.

Az én receptem egyszerübb és olcsóbb: „Besser machen!” Csináljunk különb dolgokat, mint eddig csináltunk és akkor utat törünk a nagyvilágba, ha az összkultur népek megpukkadnak is az irigységtöl.

Ha Hubay megcsinálja a dolgot, jól teszi, én sem támogatni, sem gátolni nem fogom.

Ilyesmi helyett megpróbálom [sic!] jobb dolgokat komponálni, mint eddig tettem. És ezt ajánlom édes mindnyájunknak.

Fogadja őszinte nagyrabecsülésem kifejezését.

Híve

Bp. 13. IX. 19.

Kacsoh Pcz

Mon cher Monsieur Zágon,

J'ai eu l'honneur de recevoir votre lettre et vous en remercie. Pardonnez-moi si je réponds explicitement par non à votre proposition. 
Je crois fermement que les manifestations qu'on n'obtient que pour une contre-valeur matérielle, pour ne pas dire une taxe humiliante, ne servent en rien la musique hongroise! Vous voyez, mon cher Monsieur Zágon, comment les ouvres de Ferenc Molnár et de Menyhért Lengyel parcourent le monde sans subvention et abonnements. Je ne pense pas que les Finnois paient une redevance à la Société internationale de Musique française, pourtant Sibelius et Järnefelt ${ }^{95}$ sont connus dans tout le monde civilisé.

Ma recette est plus simple et moins chère : "Besser machen! » Faisons les choses mieux que jusqu'ici et on finit par percer dans le grand monde, quand bien même les peuples civilisés en tomberaient malades d'envie.

Si Hubay entend faire la chose, il fait fort bien, je ne vais pas le soutenir ni l'empêcher.

Au lieu de cela, j'essaierai de composer de meilleures musiques que jusqu'ici. Et c'est ce que je recommande à nous tous.

Veuillez agréer l'expression de mes sentiments distingués.

Votre

Bp. 19. IX. 13.

[Pongrác Kacsoh]

\section{1.}

Billet de Michel-Dimitri Calvocoressi ${ }^{96}$ à Géza Vilmos Zágon

Non daté [Paris, le 23 février 1913] ${ }^{97}$

\section{H-Bn Département des Manuscrits, Fond XII/168, Ep. mus. 1209/a}

Manuscrit autographe signé à l'encre brune, en langue française.

Monsieur V. G. Zagon / 3 rue de l'Odéon/ Paris 6

Cher Monsieur

Tous mes remerciements pour votre interéssant $\mathrm{m}[\mathrm{anu}] \mathrm{s}$ [crit] que je vais me mettre à étudier. Aussi pour les Bartok qui me sont bien venus - je vous suis très obligé pour votre aimable empressement à m'aider. Je pars pour revenir le 9 Mars. A ce

95. Dans l'original : « Jäernefelt ».

96. Michel-Dimitri Calvocoressi (1877-1944) - musicologue, critique musical, librettiste et traducteur d'origine grecque, polyglotte, l'auteur de nombreuses biographies de musiciens. Après avoir longtemps vécu à Paris, il s'installa à Londres en 1914. Il était le collaborateur musical de plusieurs journeaux français en même temps (Comœedia illustré, Revue Française de Musique etc.), ainsi que le correspondant des organes anglais, américains, allemands et russes. Entre 1905 et 1914, il tint des conférences sur la musique contemporaine à l'École des Hautes Études Sociales de Paris. Spécialiste et promoteur efficace en France de la musique russe, il fut de 1907 à 1910 le conseiller français de la troupe de ballet et d'opéra de Sergei Diaghilev. À partir des années 1910, il était partisan et propagateur de la musique de Bartók et de Kodály, traduisant en français ou en anglais le texte de certaines de leurs œuvres vocales. On lui doit la première adaptation française du Château de Barbe-Bleue de Bartók.

97. Daté d'après le cachet postal. 
moment je serai très heureux si nous pouvons nous voir. J'ai mon piano à présent, et nous pourrons faire de la musique, non plus seulement en regarder !

Agréez mes sentiments cordiaux et dévoués

M Calvocoressi

9.2.

Carte postale illustrée de Michel-Dimitri Calvocoressi à Géza Vilmos Zágon

Oxford, le 18 août $1913^{98}$

H-Bn, Département des Manuscrits, Fond XII/168, Ep. Mus. 1209/b. Manuscrit autographe signé à l'encre noire, en langue française.

Monsieur V. G. Zágon / Hotel Central Benoît / Grande Rue / Saint Malo / Ille-etVilaine $^{99}$

Bon souvenir d'Oxford. Je viens de finir mes 4 conférences (musique française) à l'Université. En 7 bre je parlerai de la musique hongroise, en Irlande. Je vous souhaite un bon été et reste

bien votre

M Calvocoressi

\section{3.}

Lettre de Michel-Dimitri Calvocoressi à Géza Vilmos Zágon

Paris, le 30 janvier 1914

H-Bn Département des Manuscrits, Fond XII/168, Ep. Mus. 1209/e.

Lettre autographe signée à l'encre noire, sur papier à en-tête de la

« Revue Française de Musique » avec enveloppe. 1 folio (1 page inscrite).

Monsieur V. G. Zagon / 3 rue de l'Odéon / Paris 6

Paris (XVII') 164, Rue de Courcelles. Le 30 Janvier 1914

Mon cher Zagon

Je tiens d'abord à vous exprimer tous mes remerciements pour le précieux concours que vous m'avez apporté. Grâce à vous j'ai pu faire exactement ce que j'avais souhaité, et mieux encore, comme leçons sur l'école Hongroise. Je vous félicite bien 
cordialement du succès de votre Sonate qui - beaucoup d'amis me l'ont dit - a beaucoup porté. J'en suis très heureux.

Pour placer la Sonate de Kodaly dans mes conférences, ce ne sera pas très facile, vu que ce sera un rapide coup d'œil d'ensemble que je veux donner, et je ne pourrai attribuer aux Hongrois que 6 à 8 minutes en tout. Mais il y a les concerts qui vont parallèlement, et je verrai si là c'est possible. Je suppose que vous avez votre violoncelliste?

Croyez-moi

Votre tout dévoué

M Calvocoressi

\section{4.}

Lettre de Michel-Dimitri Calvocoressi à Géza Vilmos Zágon

Paris, le 15 février 1914

H-Bn, Département des Manuscrits, Fond XII/168, Ep. Mus. 1209/d.

Lettre autographe signée à l'encre noire, en langue française, sur papier à en-tête

de la «Revue Française de Musique », avec enveloppe.

1 folio (1 page inscrite).

Monsieur V G Zagon / 3 rue de l'Odéon / Paris

Paris (XVII') 164, Rue de Courcelles. Le 15-2-14.

Cher Zagon

Je ne sais par quelle sottise j'ai oublié dans un coin cette carte au lieu de l'envoyer. J'espère que vous m'excuserez et viendrez aux conférences suivantes. Vous verrez comme la Salle Villiers est jolie et commode et spacieuse.

Préférez-vous jouer le 7 ou le 14 Mars (4 h)?

Cordialement votre

M Calvocoressi 


\section{5. \\ Lettre de Michel-Dimitri Calvocoressi à Géza Vilmos Zágon}

[Paris], non datée ${ }^{100}$

H-Bn Département des Manuscrits, Fond XII/168, Ep. Mus. 1209/f.

Lettre autographe signée à l'encre noire, en langue française.

1 folio (1 page inscrite).

Mercredi

Cher ami

Voici des places pour les conférences. Si vous en voulez d'autres, je suis tout à vos ordres.

Voulez-vous jouer le 23 ? Comme je n'ai aucune réponse du Quatuor, je pense que nous pourrons faire le programme aussi large que possible, et j'userai abondamment de votre bonne volonté. Il y aura peut-être lieu, même, de jouer en deux / ies. Si vous venez le 16, nous en causerons à la fin de la conférence.

Amicalement votre

M Calvocoressi

100. Comme Calvocoressi donna des conférences, à l'École des Hautes Études Sociales, le 16, 23 et 30 janvier 1914 - le 23 et le 30 avec le concours de Zágon -, cette lettre pourrait être datée de la première partie de janvier 1914. Mais une datation pour le printemps de 1914 est également possible, voir la lettre précédante qui démontre que les conférences ont continué. 
9.6.

Lettre de Michel-Dimitri Calvocoressi à Géza Vilmos Zágon

Paris, 11 juin 1914

H-Bn, Département des Manuscrits, Fond XII/168, Ep. Mus. 1209/c

Lettre autographe signée à l'encre noire, en langue française, sur papier à en-tête

de la «Revue Française de Musique », avec enveloppe.

1 folio (1 page inscrite).

Monsieur V. G. Zagon / Budapest V/ Zoltán utca 11 / Hongrie

[Sur le recto de l'enveloppe, au crayon :]

Au moment de mettre à la poste je reçois votre lettre. Merci! J'aviserai pour Rozsav[ölgyi] / Amitiés / MC".

Paris $\left(\mathrm{XVII}{ }^{\mathrm{e}}\right)$ 164, Rue de Courcelles. Le 11 Juin

Cher ami

Excusez-moi de ne pas vous avoir encore répondu : j'attendais la lettre et le paquet que vous m'annonciez, ils ne sont pas arrivés, j'ai avec le temps oublié, et voilà que la lettre de $\mathrm{M}$. Bartok me rappelle ma négligence que je regrette vivement.

Je crois que de toute façon je ne pourrais guère vous être utile cette saison - et qu'il ne faut point donner de concert si tard, mais en préparer un pour l'automne. En ce qui concerne M. Bartok, j’ai parlé à M. Tiersot; et je lui écris par un même courrier.

J'espère que vous ne m'en voulez pas trop de mon long silence : j’ai été très surmené, et pendant tout un mois souffrant. A bientôt j'espère.

Croyez-moi

Cordialement votre

M Calvocoressi 